\title{
Recent advances in lipopolysaccharide-based glycoconjugate vaccines
}

\author{
Henderson Zhu, Christine S. Rollier \& Andrew J. Pollard
}

To cite this article: Henderson Zhu, Christine S. Rollier \& Andrew J. Pollard (2021) Recent advances in lipopolysaccharide-based glycoconjugate vaccines, Expert Review of Vaccines, 20:12, 1515-1538, DOI: 10.1080/14760584.2021.1984889

To link to this article: https://doi.org/10.1080/14760584.2021.1984889
(c) 2021 The Author(s). Published by Informa UK Limited, trading as Taylor \& Francis Group.

\section{央 Published online: 25 Oct 2021.}

Submit your article to this journal

Џلll Article views: 269

Q View related articles $\sqsubset$

View Crossmark data $₫$ 


\title{
Recent advances in lipopolysaccharide-based glycoconjugate vaccines
}

\author{
Henderson Zhu (10, Christine S. Rollier and Andrew J. Pollard
}

Oxford Vaccine Group, Department of Paediatrics, University of Oxford and the National Institute for Health Research (Nihr) Oxford Biomedical Research Centre, Oxford, UK

ABSTRACT

Introduction: The public health burden caused by pathogenic Gram-negative bacteria is increasingly prominent due to antimicrobial resistance. The surface carbohydrates are potential antigens for vaccines against Gram-negative bacteria. The enhanced immunogenicity of the O-specific polysaccharide (O-SP) moiety of LPS when coupled to a carrier protein may protect against bacterial pathogens. However, because of the toxic lipid A moiety and relatively high costs of O-SP isolation, LPS has not been a popular vaccine antigen until recently.

Areas covered: In this review, we discuss the rationales for developing LPS-based glycoconjugate vaccines, principles of glycoconjugate-induced immunity, and highlight the recent developments and challenges faced by LPS-based glycoconjugate vaccines.

Expert opinion: Advances in LPS harvesting, LPS chemical synthesis, and newer carrier proteins in the past decade have propelled LPS-based glycoconjugate vaccines toward further development, through to clinical evaluation. The development of LPS-based glycoconjugates offers a new horizon for vaccine prevention of Gram-negative bacterial infection.
ARTICLE HISTORY

Received 09 May 2021

Accepted 21 September2021

KEYWORDS

Bioconjugation; carrier protein; chemical conjugation; glycoconjugate; lipopolysaccharide; vaccine

\section{Introduction to bacterial carbohydrate conjugate vaccines}

Outer surfaces of blood-invading bacteria are formed from many components, including glycoproteins and glycolipids, which serve as virulence factors. For Gram-negative bacteria, these include lipopolysaccharide (LPS), capsular polysaccharide (CPS), and exopolysaccharide (EPS) [1] (Figure 1).

The development of vaccines derived from bacterial surface carbohydrates were initially based upon evidence accumulated in the early $20^{\text {th }}$ century. In the 1920 s, carbohydrates were first described as immunogens when capsular polysaccharides extracted from Streptococcus pneumoniae were shown to precipitate in immunized horse serum [2]. In the 1930s, observations that the loss of responses to skin tests using purified S. pneumoniae CPS in participants who recovered from pneumococcal infection pointed to the potential application of bacterial surface carbohydrates as vaccine antigens, which led to the introduction of S. pneumoniae CPSbased polysaccharide vaccines [3].

Following on, CPS-based polysaccharide vaccines against Neisseria meningitidis, and Haemophilis influenzae type b (Hib) were introduced in the late 20th century [4]. The expansion of CPS-based polysaccharide vaccines revealed several limitations through time: (1) carbohydrate vaccines are less immunogenic in infants and the elderly compared with adolescents and adults [5-7]; (2) antibody responses produced by the CPS vaccines waned quickly $[8,9]$. To address these problems, bacterial surface carbohydrates were chemically coupled to carrier proteins to enhance immunogenicity and to induce immunological memory [10]. These glycoconjugate vaccines induce a $\mathrm{T}$ cell-dependent immune response which involves the formation of memory B cells against the antigen [11]. Excellent safety and immunogenicity of CPS-based glycoconjugate vaccines in infants were shown in several earlier clinical studies [12-14].

Vaccines against bacterial pathogens had been undergoing a continuing shift from carbohydrate-based vaccines to glycoconjugate vaccines over the past decades [7]. Glycoconjugate vaccines against Hib received licensure in industrialized countries including the UK and the USA in the late 1980s and the early 1990s, with the inclusion into routine immunization for infants [15]. To date, many CPS-based conjugate vaccines were licensed for childhood vaccinations in the EU and the US (Table 1). Broad immunization in low-and-middle-income countries was made available later with support from the Gavi Alliance, which impacted significantly on the reduction of Hib- and pneumococcus-related mortality across the African meningitis belt $[16,17]$.

While CPS-based glycoconjugate vaccines have a positive impact on global health, many other Gram-negative bacteria do not have a capsule and therefore a non-CPS-based glycoconjugate vaccine is needed. Also, antimicrobial resistance (AMR) driven by the use of broad-spectrum antibiotics has highlighted the need for vaccines against Gram-negative bacteria [20]. LPS stands out as an alternative vaccine antigen to address these problems. LPS is an outer membrane glycolipid of Gram-negative 


\section{Article highlights}

- Lipopolysaccharide (LPS) is a weak vaccine antigen but can be made immunogenic by chemically conjugating with a carrier protein. Glycoconjugate vaccines have enhanced immunogenicity compared to plain polysaccharides in young and elderly age groups due to Tcell mediated immunity.

- New technologies for obtaining LPS, as well as novel carrier proteins, have generated LPS-based glycoconjugate vaccine candidates with promising yields and immunogenicity.

- Conjugation methods are increasingly well-understood, while some conjugation methods will result in glycoconjugates of random conformations, conformation-specific conjugation methods are gaining more attention.

- Several immunological caveats are present with glycoconjugate vaccines, such as pre-existing immunity to the carrier protein and the reduced immunogenicity when concomitantly administering glycoconjugate vaccines.

bacteria that facilitates immune evasion, inflammation, and antimicrobial resistance [21]. While LPS alone elicits weak immune responses and shares the same immunological inadequacies of other plain polysaccharides, LPS-based glycoconjugate vaccine candidates have demonstrated promising levels of immunogenicity against unencapsulated bacteria that have been confirmed to develop AMR, including Shigella spp, enteropathogenic Escherichia coli, and Pseudomonas aeruginosa in clinical and preclinical investigations [22-25]. Further details on the mechanisms of glycoconjugate-induced immunity and the rationale of using LPS as a vaccine antigen are discussed in the following sections.

\section{The role of conjugation in immune response}

Two working models are currently present to explain glycoconjugate-induced immunity, both involving the interactions between the glycoconjugate, B cells, and CD4 + T cells (Figure 2). Both working models initiate with the carbohydrate moiety of the glycoconjugate binding to the $B$ cell receptor (BCR). Then the glycoconjugate is endocytosed to be destined for the lysosomal compartments. In the classic working model, glycoconjugates disassemble within the lysosomal compartments, in which the liberated carrier proteins break down into smaller peptides. These peptides bind to class II major histocompatibility (MHCII) complexes in the B cell cytosol and traffic anterogradely to present these peptides for fusion with T cell receptors (TCR) on CD4 $+\mathrm{T}$ cells [26]. The binding to TCR facilitates the binding of CD80/86 and CD84, thus activating the production of cytokines such as IL-4 and IL-2, activating the proliferation of carbohydrate-specific $B$ cells and the maturation into memory $B$ cells, resulting in the production of anti-polysaccharide IgG antibodies by $B$ cells $[27,28]$.

The classic working model is based on the knowledge that MHCIl complexes cannot bind carbohydrates [29], however, in recent years, a newer working model had gained increased attention. The model suggested that carbohydrates can bind indirectly to MHCll complexes. To achieve that, it was proposed that the carrier protein within the glycoconjugate is enzymatically degraded in the lysosome, generating fragmented glycopeptides held together by the covalent linkage formed in chemical conjugation. The peptide moiety of the

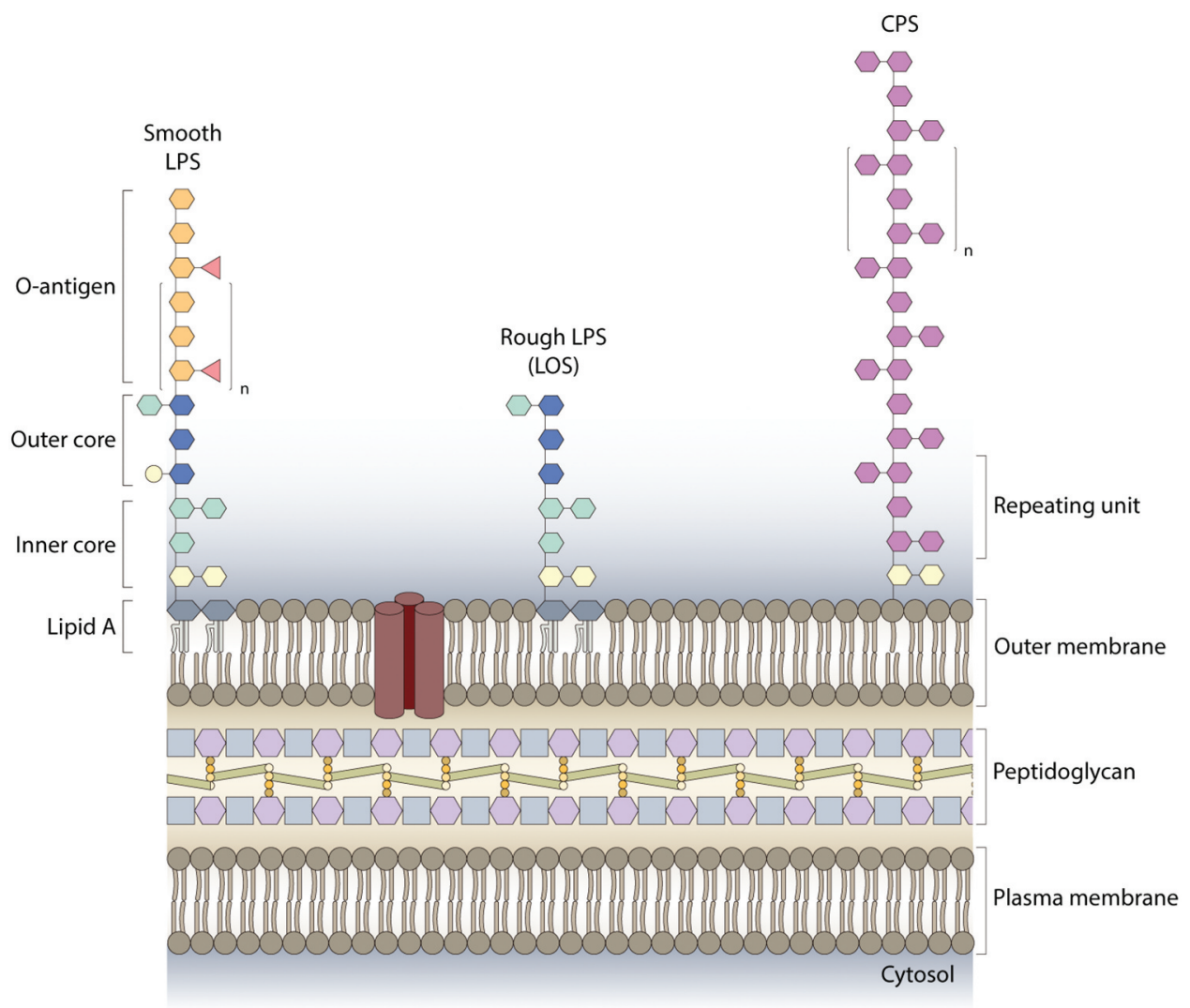

Figure 1. Outer membrane structure of gram-negative bacteria. 
Table 1. Licensed CPS-based glycoconjugate vaccines in the EU and the US $[18,19]$.

\begin{tabular}{|c|c|c|c|c|c|}
\hline Pathogen(s) protected with CPS-conjugates & $\begin{array}{l}\text { Disease(s) protected not with } \\
\text { CPS-conjugates }\end{array}$ & Carrier protein & Tradename & Manufacturer & $\begin{array}{l}\text { Approved in } \\
\text { EU and/or } \\
\text { US }\end{array}$ \\
\hline $\begin{array}{l}\text { Neisseria meningitidis serogroups } A, C, Y \text {, and } \\
\text { W- } 135\end{array}$ & None & CRM197 & Menveo & GlaxoSmithKline & US/EU \\
\hline $\begin{array}{l}\text { Neisseria meningitidis serogroups A, C, Y, and } \\
\text { W- } 135\end{array}$ & None & Diphtheria toxoid & Menactra & Sanofi Pasteur & US \\
\hline $\begin{array}{l}\text { Neisseria meningitidis serogroups } A, C, Y \text {, and } \\
\text { W- } 135\end{array}$ & None & Tetanus toxoid & Nimenrix & Pfizer & EU \\
\hline $\begin{array}{r}\text { Streptococcus pneumoniae serotypes } 1,3,4,5 \text {, } \\
6 \mathrm{~A}, 6 \mathrm{~B}, 7 \mathrm{~F}, 9 \mathrm{~V}, 14,18 \mathrm{C}, 19 \mathrm{~A}, 19 \mathrm{~F} \text { and } 23 \mathrm{~F}\end{array}$ & None & CRM197 & Prevnar 13 & Pfizer & US/EU \\
\hline $\begin{array}{l}\text { Streptococcus pneumoniae serotypes } 1,4,5,6 \mathrm{~B} \text {, } \\
\quad 7 \mathrm{~F}, 9 \mathrm{~V}, 14,18 \mathrm{C}, 19 \mathrm{~F} \text { and } 23 \mathrm{~F}\end{array}$ & None & $\begin{array}{l}\text { Haemophilus influenzae proteind } \\
\text { D, tetanus toxoid, and diptheria } \\
\text { toxoid }\end{array}$ & Synflorix & GlaxoSmithKline & EU \\
\hline Haemophilus influenzae type b & $\begin{array}{l}\text { Diphtheria, tetanus, pertussis, } \\
\text { poliomyelitis, and hepatitis } \\
\text { B }\end{array}$ & $\begin{array}{l}\text { Outer membrane protein complex } \\
\text { (OMPC) }\end{array}$ & Vaxelis & $\begin{array}{l}\text { Merck/Sanofi } \\
\text { Pasteur }\end{array}$ & US/EU \\
\hline Haemophilus influenzae type b & $\begin{array}{l}\text { Diphtheria, tetanus, pertussis, } \\
\text { poliomyelitis, and hepatitis } \\
\text { B }\end{array}$ & Tetanus toxoid & $\begin{array}{r}\text { Infanrix } \\
\text { Hexa }\end{array}$ & GlaxoSmithKline & EU \\
\hline Haemophilus influenzae type b & $\begin{array}{c}\text { Diphtheria, tetanus, pertussis, } \\
\text { and poliomyelitis }\end{array}$ & Tetanus toxoid & Pentacel & Sanofi Pasteur & US \\
\hline Haemophilus influenzae type b & None & $\begin{array}{l}\text { Outer membrane protein complex } \\
\text { (OMPC) }\end{array}$ & PedvaxHIB & Merck & US \\
\hline Haemophilus influenzae type $b$ & None & Tetanus toxoid & ActHIB & Sanofi Pasteur & US \\
\hline Haemophilus influenzae type $b$ & None & Tetanus toxoid & Hiberix & GlaxoSmithKline & US \\
\hline
\end{tabular}

glycopeptides acts like an anchor that binds to MHCII complexes, allowing the glycopeptide-bound $\mathrm{MHCll}$ to present its carbohydrate moiety to $T$ cell receptors on a unique subset of $\mathrm{CD}^{+} \mathrm{T}$ cells, designated as carbohydrate-specific $\mathrm{T}$ cells (Tcarbs). Thereafter, the $T$ cell receptor-binding can induce $B$ cell proliferation, maturation, and the production of anti-polysaccharide IgG in an analogous way to the classical working model $[27,30]$. This newer working model suggested that glycoconjugate vaccines may benefit from a 'sun'-type conformation as supposed to a 'lattice'-type conformation, as the prior would allow the formation of more glycopeptides due to the abundant covalent linkage. Reports have been emerging to suggest that the two mechanisms may be co-existent [27,31]. Thus, further investigations on the biochemistry of Tcarbs can be helpful in elucidating glycoconjugate-induced immunity and optimizing vaccine design [28].

\section{LPS as a vaccine antigen}

The outer membrane of most Gram-negative bacteria is predominantly made up of LPS [32], which can be further subcategorized into smooth LPS and rough LPS. Smooth LPS is the most common form of LPS, composed of three moieties, a hydrophobic lipid A, a non-repeating rough core oligosaccharide, and a hydrophilic O-specific polysaccharide (O-SP). Rough LPS differentiates from smooth LPS by the absence of O-SP [33] (Figure 1). LPS functions as a virulence factor in several ways. Firstly, the continuum of LPS along the bacterial surface forms a non-fluid permeability barrier that blocks the entrance of certain antimicrobial molecules [34,35]. Also, the long and outward-projecting O-SP moiety prevents the deposition of complement on the surface of smooth strain bacteria, contributing to immune evasion [36].

In many instances, antibodies targeting LPS confer protection against bacterial infections. In vitro studies showed antibodies to the O-Ag (O-SP and the core oligosaccharide) induced protection against Klebsiella pneumoniae, Vibrio cholerae, N. meningitidis, and Salmonella enterica by mediating opsonophagocytosis, complement-mediated lysis, and agglutination [37-40]. It has been recently shown that anti-LPS IgG within the mucus layer of the gastrointestinal mucosa can crosslink with mucin to capture $S$. Typhimurium on the mucin mesh, thus inhibiting the flagellum-based bacterial motility [41]. This capturing of bacteria highlighted a new, but potentially conserved mechanism of protection, likely involved in the protection against other enteric pathogens. The neutralizing effect of the O-Ag-specific antibodies is weaker in encapsulated bacteria, such as encapsulated serotypes of Klebsiella pneumoniae, because the shielding created by CPS can lower the accessibility of anti-LPS antibodies to the LPS [42].

In higher organisms, the toxicity of LPS is conferred by the lipid A moiety, which can bind to a protein complex formed by Toll-like receptor 4 (TLR4) and myeloid differentiation factor 2 (MD2) [43]. Upon binding with LPS, TLR4 oligomerizes to allow the recruitment of adaptor proteins including myeloid differentiation primary response 88 (Myd88) and TIR domain-containing adaptor inducing IFN- $\beta$ (TRIF) through the Tollinterleukin-1 receptor (TIR) domains of TLR, which subsequently lead to the activation of the transcription factor 
nuclear factor-KB (NF-KB), inducing the secretion of proinflammatory cytokines including IL-1, IL-6, and IFN- $\gamma$. Release of these cytokines activate signaling cascades which typically cause fever, inflammation, and tissue damage, however in severe cases, might cause hypotension and septic shock [4345]. Thus, detoxification techniques were developed to convert LPS into vaccine candidates, including alkaline and acid detoxification to degrade or remove lipid $A$, respectively $[46,47]$. Between these detoxification methods, alkaline detoxification may result in the incomplete removal of lipid $A$, which may also cause incomplete detoxification [48]. Due to this drawback, detoxification of LPS is now more commonly performed by acid hydrolysis, which removes the whole lipid A moiety from the LPS, producing O-Ag. Earlier attempts to detoxify LPS isolated from E. coli and S. Typhimurium showed low immunogenicity in mice challenge models, highlighting the need for conjugation to suffice potency $[49,50]$.

The development of LPS-based vaccines was also stagnated by the low harvesting efficiency of LPS from bacterial culture. In the $20^{\text {th }}$ century and early $21^{\text {st }}$ century, the extraction of LPS

a

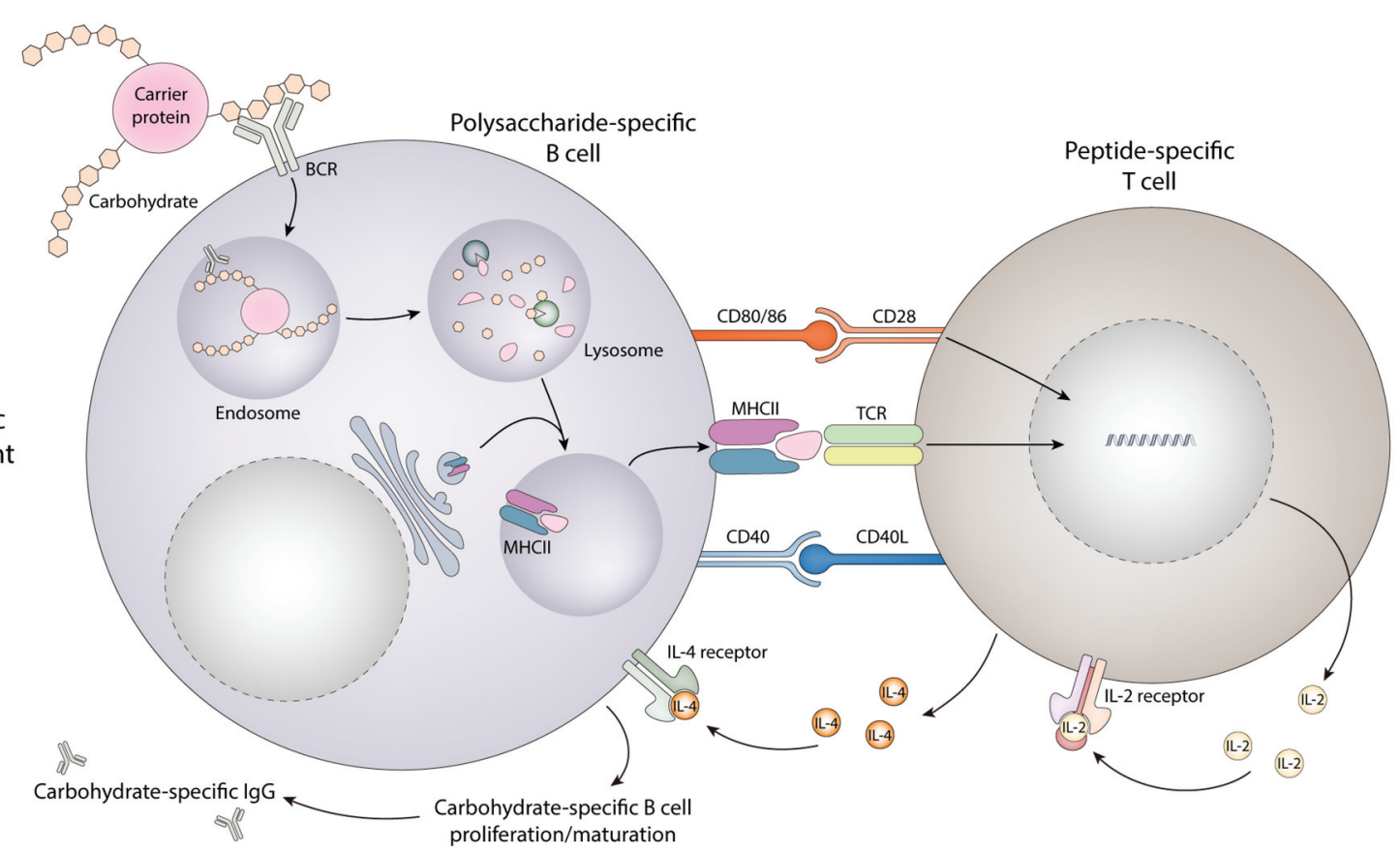

b

Peptide-specific T cell-dependent model

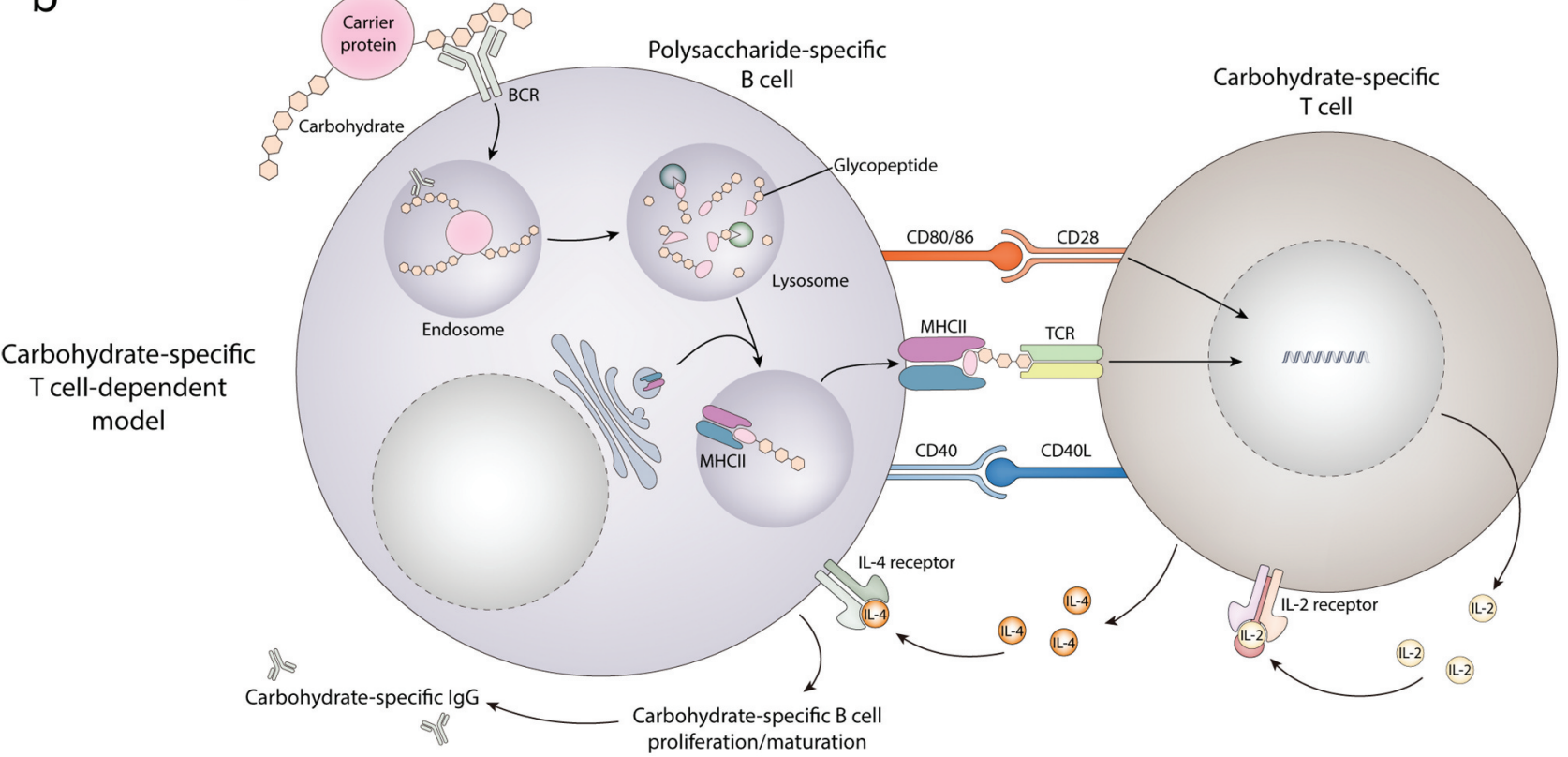

Figure 2. Working models for T-cell dependent immunity induced by glycoconjugate vaccines. Both mechanisms involve BCR-mediated intake of glycoconjugates resulting in the activation of T cells, resulting in the secretion of cytokines inducing $B$ cell proliferation and maturation. (a) The peptide-specific T cell-dependent model involves the presentation of peptide to a peptide-specific $T$ cell. (b) The carbohydrate-specific $T$ cell-dependent model involves the presentation of glycopeptides to carbohydrate-specific T cells. This figure is adapted from Avci et al. 2011. 
is a laborious process that made the industrial-scale production of LPS-based derivatives costly. It was only more recently that LPS extraction had been adapted to industrial-scale operations, which will be discussed in the next section [51].

\section{Obtaining LPS for generating glycoconjugates}

\subsection{Harvesting LPS from bacterial culture}

The most common method of isolating smooth LPS from whole bacteria in both industrial and laboratory settings is the hot phenol-water method developed by Westphal \& Jann [52]. This process involves an initial thermal lysis of suspended ground freeze-dried bacteria, followed by centrifugation and resuspension into a phenol-water mixture (typically 1:1) [53]. Due to the varied hydrophobicity of carbohydrates and proteins, the bacterial material dissolved in the phenolwater mixture partition to either phenol or water depending on their hydrophobicity. The amphipathic LPS, comprising the hydrophilic O-SP domain, is enriched in the aqueous phase, whereas proteins partition into phenol [52]. Most preclinical and clinical LPS-based vaccine candidates using LPS harvested bacterial culture use hot phenol-water method in their production, including O-SP-conjugate vaccines for $V$. cholerae, $S$. dysenteriae type I, S. flexneri $2 \mathrm{a}$, and S. sonnei $[54,55]$.

Refinements to the hot phenol-water method were made over time to address several aims: to adapt to different scales of operation, to improve yield, and to improve purity $[56,57]$. Notably, the initial drawback of the hot phenol-water method is the enrichment of contaminants in the preparation, including RNA, DNA, and lipoproteins. These contaminants are difficult to isolate and can confound downstream applications relying on the biological properties of the LPS, such as the production and validation of glycoconjugates. To minimize these contaminants, enzymatic pre-treatments with RNase A, DNase I, and proteinase $\mathrm{K}$ before the phenol-water extraction are now standard [58-60]. To achieve an even higher purity of LPS with the aim of removal of remaining lipoproteins, repurification methods has been developed using phenol extraction [61].

Despite achieving a high yield and purity using hot phenolwater extraction, the method is demonstrated to be time-consuming (requires three to four days), costly (involving multiple steps including enzymatic pre-treatment, multiple centrifugations, and detoxification to remove lipid A), and can lead to toxic remnants of phenol. Preliminary work done in the late 1980s and early 1990s proposed another method suitable for the industrial-scale isolation of LPS [62]. The method worked on the principle that the ketosidic bond between the core oligosaccharide and the lipid A moieties is acid-labile; thus, the O-Ag can be liberated after persistent heating under an acidic condition. Due to the increasing demand for LPS in glycoconjugate vaccine production, recent works had adapted the technique to industrial operations by making it compatible with industrial sterilize-in-place fermenters, allowing microbial fermentation and acetic acid hydrolysis to happen sequentially in situ, followed by harvesting via centrifugation [51]. The subsequent supernatant can then be purified using a series of tangential flow filtration, cation-exchange chromatography, and acid/base precipitation to remove residual peptides and nucleic acids. The method was successful in isolating the O-Ag from S. Paratyphi A $(\mathrm{O}: 2)$, S. Typhimurium $(0: 4,5)$, and $S$. Enteritidis $(O: 9)$ in higher quantities $[51,63]$. This method was proven viable to be used in LPS-based glycoconjugate vaccine production as demonstrated by a vaccine candidate against $S$. Typhimurium $(0: 4,5)$, which contained O-Ag conjugated to CRM197. Administering the vaccine candidate in mice induced $>10$-fold greater increase in anti-O-Ag IgG titers compared with pre-immune serum, while also showing a two-log reduction in bacterial load in the spleen and liver of immunized mice after bacterial challenge [63].

Alternatively, efficient extraction methods for isolating rough LPS were established based on phenol/chloroform/ light petroleum ether extraction developed by Galanos, Luderitz \& Westphal [64]. This method was used in the preclinical development of glycoconjugate vaccines against rough mutant strains of Escherichia coli, including strains Rc, R1, R2, R3, R4, and K-12 [65]. However, the outcome of the study suggested that the rough LPS conjugates against $E$. coli strain with the R1 core were not immunogenic in cows. Other methods were also developed to isolate both smooth and rough LPS depending on the bacterial strain used, including the Darveau \& Hancock method, which relied on the precipitation of LPS with magnesium chloride and ethanol [66].

\subsection{Cell-free harvesting of O-SP through chemical synthesis}

The chemical synthesis of LPS mimics is a cell-free, standardized, and scalable alternative to the isolation of LPS from bacterial cell cultures. This approach brings several critical advantages for vaccine production and development, including high reproducibility, avoidance of batch-batch variation seen in bacterial cultures, and free of bacterial remnants [67]. Beyond acting as a vaccine candidate, synthetic O-SP can also act as a tool to determine the immunogenicity of different lengths of O-SP in glycoconjugates and assess the level of immunogenicity elicited by different non-reducing end sugars [68]. Recently, Colombo, Pitirollo \& Lay constructed an informative review on the advances in synthetic glycoconjugate vaccines over the past decades [69].

The first breakthrough in glycoconjugates with LPS mimics was demonstrated by an O-SP-mimic-tetanus toxoid conjugate vaccine candidate SF2a-TT15 developed by the Institut Pasteur. The vaccine candidate had three repeating units of a pentasaccharide mimicking the O-SP of S. flexneri 2a. In a recent phase 1 study, the vaccine candidate induced a strong antibody response, demonstrated by anti- LPS IgG seroconversion ( $\geq$ four-fold rise in antibody titer 28 days after vaccination) in all vaccine recipients, while sustaining a high level of antiLPS IgG with no significant decline 84 days after vaccination in the alum-adjuvanted cohort. The vaccine candidate was also well-tolerated, with no serious or severe adverse events [23]. Currently, synthesized LPS mimics are implemented in preclinical studies to propose vaccine candidates against other enteric pathogens. A glycoconjugate vaccine candidate incorporating synthetic core oligosaccharide of Neisseria meningitidis demonstrated IgG agglutination in vitro and showed strong recall responses after reimmunisation 260 days from the initial priming [70]. Another glycoconjugate vaccine candidate, 
utilizing the hexasaccharide fragment of Vibrio cholerae 0:1 (Ogawa) O-SP conjugated to BSA induced a robust anti-LPS IgG response and showed a vaccine efficacy of $86 \%$ in a mice challenge model with one $50 \%$ lethal dose (LD50) [71].

To date, there are four preclinical and one phase 1 LPS based glycoconjugates incorporating chemically synthesized glycans, including vaccine candidates against S. dysenteriae, Vibrio cholerae, Neisseria meningitidis, Bordetella pertussis, and S. flexneri [23,70-74]. The emergence of these synthetic carbohydrate-based glycoconjugate vaccine candidates results from evolving automated glycan assembly (AGA) technologies [75]. The introduction of the first commercial AGA platforms (Glyconeer 2.1 synthesizer) [76] in 2017 showed the synthesis of hexasaccharides with purities $>99 \%$. To synthesize the oligosaccharide, the AGA platform functions by executing reaction cycles that assemble appropriate fluorenylmethyloxycarbonyl (Fmoc) protecting group-conjugated building block sugars to polystyrene-based resins. The oligosaccharide is then cleaved by ultraviolet (UV)-irradiation, while quality control is carried out by HPLC, MS, and NMR. Recent advances in AGA quality control allowed real-time monitoring of reaction cycles and may improve the platform's efficiency further, preparing it for commercial-scale production of high-quality oligosaccharides [77].

More recent reports had also described the chemoenzymatic synthesis of oligosaccharides, which involves the enzymatic polymerization of chemically synthesized monosaccharides. This method had been applied to generate meningococcal CPS for glycoconjugate vaccine production $[26,78]$. However, while results have been published describing the chemoenzymatic synthesis of core oligosaccharide of E. coli 0157 for enzyme activity assays [79], the adaptation of this method to generate the O-SP of LPS is still underway.

\section{Recent developments in carrier molecules}

Conjugation technology allowed previously T-cell independent antigens to become potent T-cell dependent immunogens. Carrier proteins seen extensively in LPS-based conjugate vaccines to date include tetanus toxoid (TT), diphtheria toxoid (DT), cross-reactive material 197 (CRM197, a modified nontoxic mutant of DT), and bovine serum albumin (BSA; in proof-ofconcept phase only) (Table 2). These carrier proteins represent most of the carrier proteins present in clinical and preclinical LPS-based glycoconjugate vaccines. These carriers are timeproven and have been manufactured on large scales. Other conventional carrier proteins, which are well-documented in past reviews $[80,81]$, include diphtheria toxoid (DT), meningococcal outer membrane protein complex (OMPC), keyhole limpet hemocyanin (KLH), ovalbumin (OVA), recombinant exoprotein A of Pseudomonas aeruginosa (rEPA), and $H$. influenzae protein D (HiD).

Aside from the well-documented carriers, novel carriers recently experimented in preclinical LPS-based glycoconjugate vaccine candidates include nanoparticle-based carrier proteins and peptide-based dual-role carriers, both being noteworthy considering their potentially higher immunogenicity compared with conventional carriers.

\subsection{Nanoparticle-based carriers}

\subsubsection{Gold nanoparticles}

Most currently licensed glycoconjugate vaccines with CPSbased carbohydrates have a 'lattice'-type conformation [91]. In contrast, 'sun'-type glycoconjugates were shown to induce higher IgG titer against $S$. sonnei and $S$. dysentariae type 1 compared with the conventional 'lattice'-type configuration [72,92]. The advantage to AuNPs is that protein and carbohydrate linkers can conjugate onto AuNPs in a 'sun'-type conformation, where thiol ends of thiolated peptides/glycans attach to the gold particle [93]. This property allowed AuNPpeptide-glycan conjugates to elicit robust immune responses toward both the carbohydrate and peptide moieties [94].

The immunogenicity of AuNP-based glycoconjugates is based on the ability to enter antigen-presenting cells (APCS) such as the dendritic cells and B cells. The rate of internalization of AuNPs into DCs varies depending on the shape and size. Smaller, rod-shaped AuNPs are more readily internalized into DCs and perinuclearly localized [95]. In contrast to DCs where AuNPs are internalized more readily, AuNPs are 10-fold less internalized in $B$ cells while remaining nontoxic to $B$ cells when incubated in culture [96]. Improving uptake rates of AuNPs is of interest to develop more potent nanoparticlebased vaccine candidates.

Recent work on preclinical Burkholderia mallei LPS-based glycoconjugate candidates have incorporated AuNPs. The vaccine candidates were constructed in two steps: an initial conjugation was performed between the AuNP and a synthetic peptide antigen, followed by a second conjugation of LPS onto the peptides pre-decorated on the AuNPs [94]. By doing this, the AuNP conjugate carries both peptide and carbohydrate antigens. The vaccine candidates demonstrated high levels of protection shown by $100 \%$ survival in mice challenged with 50 times LD50.

Besides the application in LPS-based glycoconjugate vaccines, AuNP-based carriers has also been conjugated to CPS. CPS-AuNP vaccine candidates for Streptococcus pneumoniae type 14 have also induced anti-CPS IgG responses in murine models. The vaccine candidates were composed of AuNP conjugated to varied ratios of OVA 323-339 peptide, D-glucose, and synthetic branched tetrasaccharide representing a single repeat of the Streptococcus pneumoniae type 14 CPS. While the best candidate yielded an IgG response representative of one log10 less than the CPS-CRM197 positive control, mouse serum from CPS-AuNP-administered mice had a $75 \%$ phagocytic capacity compared with CPS-CRM197-administered mice. The results show that immunity can be induced from vaccines constructed with this platform, but further optimizations can be necessary [93].

\subsubsection{Poly lactic-co-glycolic acid nanoparticles}

PLGA-NPs are biodegradable polymeric esters formed from a 1:1 ratio of lactic acids and glycolic acids [97]. Due to the intake of PLGA-NPs into APCs such as DCs, these constructs were used to explore the functionality both as a vaccine adjuvant carrier to deliver peptide and carbohydrate-based adjuvants, and as a vaccine candidate itself, either by the conjugation of antigens on its surface or by encapsulating 
Table 2. Clinical and preclinical LPS-based glycoconjugate vaccine candidates.

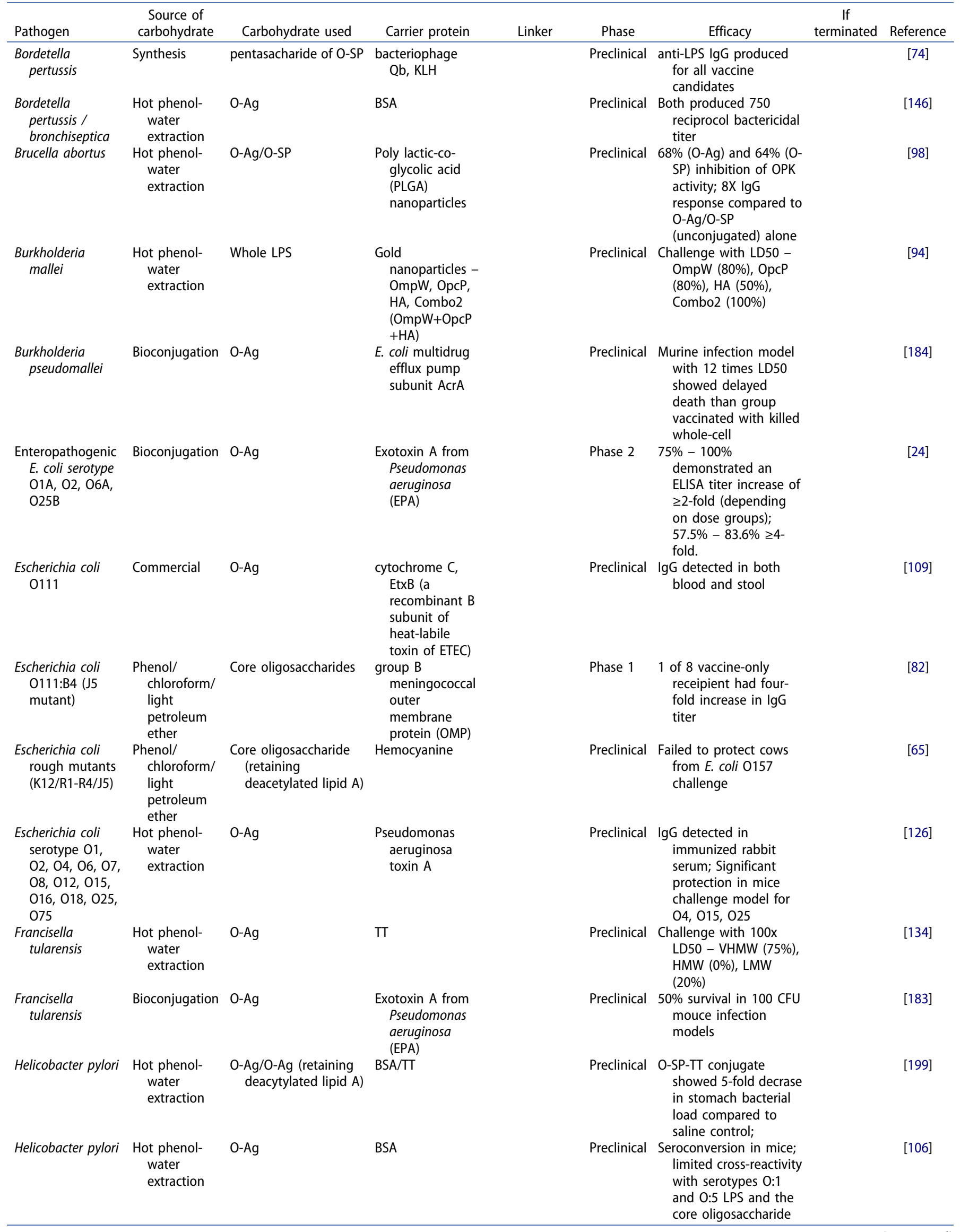


Table 2. (Continued).

\begin{tabular}{|c|c|c|c|c|c|c|c|c|}
\hline Pathogen & $\begin{array}{c}\text { Source of } \\
\text { carbohydrate }\end{array}$ & Carbohydrate used & Carrier protein & Linker & Phase & Efficacy & $\begin{array}{c}\text { If } \\
\text { terminated }\end{array}$ & Reference \\
\hline $\begin{array}{l}\text { Mannheimia } \\
\text { haemolytica }\end{array}$ & $\begin{array}{l}\text { Hot phenol- } \\
\text { water } \\
\text { extraction }\end{array}$ & $\begin{array}{l}\text { O-Ag (retaining } \\
\text { deacytylated lipid A) }\end{array}$ & CRM197 & & Preclinical & $\begin{array}{l}\text { Bacterial killing with } \\
\text { immunized rabbit } \\
\text { serum }\end{array}$ & & [83] \\
\hline $\begin{array}{l}\text { Moraxella } \\
\text { catarrhalis }\end{array}$ & $\begin{array}{l}\text { Hot phenol- } \\
\text { water } \\
\text { extraction }\end{array}$ & $\begin{array}{l}\text { O-Ag (retaining } \\
\text { deacytylated lipid A) }\end{array}$ & CRM197 & & Preclinical & $\begin{array}{l}\text { Bacterial killing with } \\
\text { immunized rabbit } \\
\text { serum }\end{array}$ & & {$[84]$} \\
\hline $\begin{array}{l}\text { Moraxella } \\
\quad \text { catarrhalis } \\
\text { serotype A, B, C }\end{array}$ & $\begin{array}{l}\text { Hot phenol- } \\
\text { water } \\
\text { extraction }\end{array}$ & Core oligosaccharides & TT/CRM197 & & Preclinical & $\begin{array}{l}\text { Bacterial killing with } \\
\text { immunized mice } \\
\text { serum }\end{array}$ & & [197] \\
\hline $\begin{array}{l}\text { Neisseria } \\
\quad \text { meningitidis }\end{array}$ & Synthesis & Core oligosaccharides & CRM197 & & Preclinical & $\begin{array}{l}\text { Successful re- } \\
\text { immunization } \\
\text { observed at } d=267 ; \\
\text { Confocal microscopy } \\
\text { verifies bacteria } \\
\text { bound to serum lgG }\end{array}$ & & {$[70]$} \\
\hline $\begin{array}{l}\text { Neisseria } \\
\quad \text { meningitidis }\end{array}$ & $\begin{array}{l}\text { Hot phenol- } \\
\text { water } \\
\text { extraction }\end{array}$ & Core oligosaccharides & CRM197 & & Preclinical & $\begin{array}{l}\text { Post immunization } \\
\text { rabbit sera able to } \\
\text { perform }>=50 \% \\
\text { bacteria killing in } \\
\text { bactericidal assay } \\
\text { after }>2048 \text {-fold } \\
\text { dilution }\end{array}$ & & [115] \\
\hline $\begin{array}{l}\text { Pseudomonas } \\
\text { aeruginosa } \\
\text { serotype } 6,11\end{array}$ & $\begin{array}{l}\text { Phenol/ } \\
\text { chloroform/ } \\
\text { light } \\
\text { petroleum } \\
\text { ether }\end{array}$ & $\mathrm{O}-\mathrm{Ag}$ & BSA & & Preclinical & $\begin{array}{l}\text { Survival with LD50 - up } \\
\text { to } 100 \%\end{array}$ & & {$[85]$} \\
\hline $\begin{array}{l}\text { Pseudomonas } \\
\text { aeruginosa } \\
\text { serotype } \\
1,2,3,4,5,6,10,11\end{array}$ & $\begin{array}{l}\text { Hot phenol- } \\
\text { water } \\
\text { extraction }\end{array}$ & $\mathrm{O}-\mathrm{Ag}$ & $\begin{array}{l}\text { Exotoxin A from } \\
\text { Pseudomonas } \\
\text { aeruginosa } \\
\text { (EPA) }\end{array}$ & & Phase 1 & $\begin{array}{l}\text { Halved cases of } P \text {. } \\
\text { aeruginosa chronic } \\
\text { infection; } \\
\text { seroconversion in all } \\
\text { mice }\end{array}$ & & [129] \\
\hline $\begin{array}{l}\text { Salmonella } \\
\text { enterica serovar } \\
\text { Enteritidis }\end{array}$ & $\begin{array}{l}\text { Darveau and } \\
\text { Hancock }\end{array}$ & Core oligosaccharides & $\begin{array}{l}\text { FliC (flagellin)/ } \\
\text { CRM197 }\end{array}$ & & Preclinical & $\begin{array}{l}\text { Challenge with } 5 X \text { LD50 } \\
\text { - vaccine efficacy } \\
91.7 \% \text { in mice }\end{array}$ & & [144] \\
\hline $\begin{array}{l}\text { Salmonella } \\
\text { enterica serovar } \\
\text { Paratyphi }\end{array}$ & $\begin{array}{l}\text { Hot phenol- } \\
\text { water } \\
\text { extraction }\end{array}$ & $\mathrm{O}-\mathrm{Ag}$ & diphtheria toxoid & $\begin{array}{l}\text { Adipic acid } \\
\text { dihydrazide } \\
(\mathrm{ADH})\end{array}$ & Preclinical & $\begin{array}{l}\text { Conjugate IgG titer } p \\
<0.05 \text { compared to } \\
\text { LPS administered } \\
\text { alone }\end{array}$ & Terminated & {$[145]$} \\
\hline $\begin{array}{l}\text { Salmonella } \\
\text { enterica serovar } \\
\text { Paratyphi } \mathrm{O} 2\end{array}$ & $\begin{array}{l}\text { Hot phenol- } \\
\text { water } \\
\text { extraction }\end{array}$ & $\mathrm{O}-\mathrm{Ag}$ & CRM197 & & Preclinical & $\begin{array}{l}\text { Seroconversion in all } \\
\text { mice; significantly } \\
\text { more immunogenic } \\
\text { than O-SP alone }\end{array}$ & & [120] \\
\hline $\begin{array}{l}\text { Salmonella } \\
\text { enterica serovar } \\
\text { Typhimurium }\end{array}$ & $\begin{array}{c}\text { Darveau and } \\
\text { Hancock }\end{array}$ & $\mathrm{O}-\mathrm{Ag}$ & BSA, OVA, FliC & & Preclinical & $\begin{array}{l}\text { Survival with LD50 - BSA } \\
(70 \%), \text { OVA }(77.8 \%), \\
\text { FliC (80\%); Vaccine } \\
\text { efficacy - BSA } \\
(56.5 \%) \text {, OVA }(60.5 \%), \\
\text { FliC }(74.1 \%)\end{array}$ & & [141] \\
\hline $\begin{array}{l}\text { Salmonella } \\
\text { enterica serovar } \\
\text { Typhimurium }\end{array}$ & $\begin{array}{l}\text { Direct acid } \\
\text { hydrolysis }\end{array}$ & $\begin{array}{l}\text { O-Ag (retaining } \\
\text { deacytylated lipid A) }\end{array}$ & CRM197 & & Preclinical & $\begin{array}{l}\text { 2-log reduction in } \\
\text { bacterial burden in } \\
\text { immunized mouse } \\
\text { spleen and liver }\end{array}$ & & {$[63]$} \\
\hline $\begin{array}{l}\text { Salmonella } \\
\text { enterica serovar } \\
\text { Typhimurium }\end{array}$ & $\begin{array}{l}\text { Direct acid } \\
\text { hydrolysis }\end{array}$ & $\mathrm{O}-\mathrm{Ag}$ & CRM197 & & Preclinical & $\begin{array}{l}\text { Seroconversion in most } \\
\text { mice; all } \\
\text { glycoconjugates } \\
\text { induced bactericidal } \\
\text { antibodies; } 3 \text { to } 100 \text { - } \\
\text { fold increase in anti- } \\
\text { O-SP IgG titers } \\
\text { depending on O-SP } \\
\text { per CRM197 }\end{array}$ & & [148] \\
\hline $\begin{array}{l}\text { Shigella } \\
\quad \text { dysenteriae type } \\
1\end{array}$ & $\begin{array}{l}\text { Synthesis/Hot } \\
\text { phenol- } \\
\text { water } \\
\text { extraction }\end{array}$ & $\begin{array}{l}\text { tetra-,octa-, dodeca-, } \\
\text { and } \\
\text { hexadecasaccharide } \\
\text { of O-SP and isolated } \\
\text { O-SP }\end{array}$ & $\begin{array}{l}\text { HSA (human } \\
\text { serum albumin) }\end{array}$ & & Preclinical & $\begin{array}{l}\text { anti-LPS IgG produced } \\
\text { for all experimental } \\
\text { vaccine candidates, } \\
\text { lowest for isolated O- } \\
\text { SP-HSA conjugate }\end{array}$ & & [68] \\
\hline $\begin{array}{l}\text { Shigella } \\
\text { dysenteriae type } \\
1\end{array}$ & Bioconjugation & $\mathrm{O}-\mathrm{Ag}$ & $\begin{array}{l}\text { Exotoxin A from } \\
\text { Pseudomonas } \\
\text { aeruginosa } \\
\text { (EPA) }\end{array}$ & & Phase 2 & $\begin{array}{l}100 \% \geq 4 \text {-fold increase in } \\
\text { LPS-specific serum lgG } \\
\text { in Phase } 1 \text { (Phase } 2 \\
\text { unpublished) }\end{array}$ & & {$[86]$} \\
\hline
\end{tabular}


Table 2. (Continued).

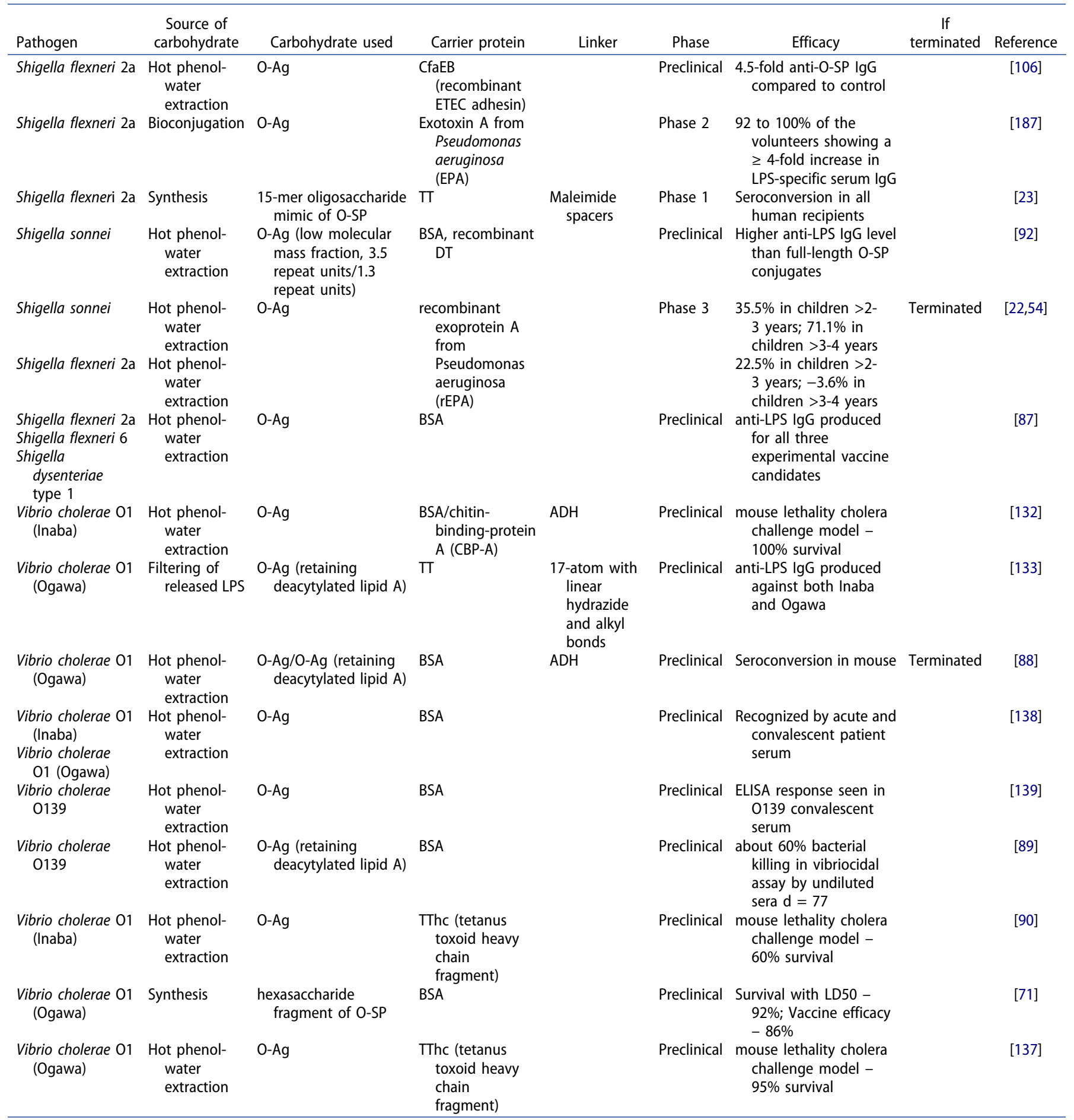

the antigens $[98,99]$. Antigens encapsulated by PLGA-NPs were shown to be released in the cytosol of DCs followed by binding $\mathrm{MHCll}$ complexes, allowing the presentation of the bound antigens to CD4 + T cells [100]. Several vaccine candidates were developed using PLGAs-NPs entrapping peptidebased antigens, however the immunogenicity varied significantly between one vaccine candidate and another [101-103].
Recent PLGA-NP-LPS/O-PS vaccine candidates for Brucella abortus showed that PLGA-based platform could produce glycoconjugate vaccine candidates in a 'sun'-like conformation [98]. The vaccine candidate comprised LPS/O-SP of Brucella abortus conjugated onto hollow PLGA-NPs. In mice, the vaccine candidates elicited an eight-fold greater increase in antiLPS IgG response when administered in mice than LPS or O-SP 
alone, demonstrating the proof-of-concept for producing glycoconjugate vaccines with this platform [98].

\subsection{Dual-role peptide-based carriers}

Modern bioinformatics allows the identification of pathogenspecific peptide antigens in which some can act both as antigen and as a carrier protein, thus termed dual-role peptide-based carriers. Dual-role peptide-based carriers allow antibody responses to be directed toward both the carrier and the carbohydrate, potentially enabling an additional layer of protection by anti-carrier antibodies [104]. In theory, this approach can also induce protection against more than one pathogen when the carrier and the carbohydrate are derived from different pathogens [105]. Meanwhile, using dual-role peptide-based carriers is also beneficial in alleviating carrierinduced epitopic suppression (CIES), which will be described later in this review.

Recent LPS-based glycoconjugate vaccine candidates have demonstrated the potential of dual-role peptide-based carriers as both a protective antigen against additional pathogens, or as an extra layer of protection against the same pathogen as the O-SP. In the case of protection against additional pathogens, a recent glycoconjugate vaccine candidate against $S$. flexneri $2 a$ with $\mathrm{O}-\mathrm{Ag}$ conjugated to $\mathrm{CfaEB}$, a recombinant carrier protein composed of the major pilin subunit ( $\mathrm{CfaB}$ ) and a minor adhesive subunit (CfaE) of enterotoxic Escherichia coli (ETEC), showed seroconversion with both anti-O-SP and anti-CfaEB IgG titers in mice [106]. The presence of anti-O-SP is a correlate of protection against $S$. flexneri $2 a$ [107], while $\mathrm{CfaB}$ and $\mathrm{CfaE}$ are also protective antigens against ETEC [108]. Additionally, another enterohemorrhagic Escherichia coli $\mathrm{O} 111$ glycoconjugate comprising the O-SP of E. coli $\mathrm{O} 111$ conjugated to the nontoxic $B$ subunit of heatlabile toxin of ETEC (EtxB) induced anti-lgG and anti-EtxB antibodies, which are both correlates to protection against ETEC $[109,110]$.

Besides LPS-based glycoconjugates, dual-role peptide-based carriers have been used in many glycoconjugate vaccine candidates. Perhaps the most notable example is the non-typeable Haemophilus influenzae (NTHi) protein D incorporated as the carrier for eight out of ten serotypes covered by the licensed pneumococcal polysaccharide and NTHi protein D conjugate vaccine (Synflorix, GlaxoSmithKline Biologicals). In a phase 3 study, the pneumococcal polysaccharide and NTHi protein D conjugate vaccine demonstrated opsonophagocytic activity (OPA) titers of $\geq 8$-fold against the pneumococcal pathogens, while also eliciting a 3.5-fold increase of anti-protein D $\lg G$ in children that have not received pneumococcal vaccines previously, thus inducing an immune response against both the CPS moiety and the carrier protein [111]. Other examples of dual-role carriers include a group A Streptococcus vaccine candidate with group A Streptococcus carbohydrate (GAC) conjugated to Streptococcus streptolysin O (SLO), which elicited higher antiGAC IgG titers compared with GAC-CRM197 conjugates [105]. Another example is a pneumococcal CPS-hepatitis B surface antigen ( $\mathrm{HBsAg})$ conjugate vaccine candidate, which showed potent $\mathrm{T}$ cell-dependent immune responses against both the CPS and the carrier protein [112].
The approach of combining carbohydrate antigen and carrier proteins from different origins is reminiscent of a previous study that showed $\Pi$ and DT conjugates confer protection against lethal challenges of both toxins in mice [113]. However, there have not yet been investigations to determine if novel dual-role peptide-based carriers, besides protein $D$ in pneumococcal polysaccharide and NTHi protein D conjugate vaccine, will induce antibody responses against both the carbohydrate antigen and the carrier protein in humans. The use of dual-role carriers may benefit from site-specific conjugation methods to retain important epitopes with the aim of eliciting a robust immune response to the carrier protein, which will be discussed in the following section.

\section{Chemical conjugation methods}

To date, multiple ways to conjugate carrier proteins and glycans have been used in the preclinical development of LPS-based glycoconjugate vaccines to achieve different conformations (Table 3; Figure 3). The high-value nature of carbohydrates and carrier proteins has led to a requirement for high conjugation efficiency. Thus, the ideal conjugation method would aim to maximize the preservation of carbohydrates and carrier proteins to ensure sufficient immunogenicity. To achieve this, conjugation techniques need to be carried out under temperature, $\mathrm{pH}$, and media that best resemble physiological conditions [114]. Glycoconjugates can be present in two conformations, 'sun'-type conformation is resulted from single-point attachments between glycans and the central carrier protein, whereas the 'lattice'-type conformation is resulted from multiple-point attachment between a single glycan and several carrier proteins (Figure 3). Also, recent preclinical glycoconjugate vaccine candidates had reflected an increased awareness that the steric hindrance arising from directly conjugating carbohydrate to a carrier protein would require a linker or spacer to evade. At the same time, different linkers may also result in varied immunogenicity [115]. In this section, chemical conjugation methods used for past clinical and preclinical LPS-based vaccine candidates are discussed.

\subsection{Reductive amination}

One of the most implemented conjugation methods in glycoconjugate vaccine production is via reductive amination $[118,119]$. Licensed vaccines conjugating via this method include CPS-based conjugate vaccines against 13 serotypes of S. pneumoniae (Prevnar13; Pfizer, USA).

Reductive amination involves the selective mild oxidation of reducing or non-reducing sugar residues to form aldehyde groups. The aldehydes form Schiff base intermediates upon interacting with lysine residues present on the carrier protein. The reduction of these Schiff intermediates via the addition of borate buffer generates stable glycoconjugates. The addition of linkers, such as adipic acid dihydrazide (ADH), can be incorporated in reductive amination to evade steric hindrance and facilitate coupling of protein to the sugar component $[115,120]$.

The merit of this approach is two-fold. Firstly, the simplicity of the workflow allows minimization of costs and loss of materials during the process. At the same time, synthetic sugars can also 
adapt to this workflow by treating with aqueous ammonium bicarbonate to activate the oligosaccharide by transforming other functional groups into aldehyde [121]. However, reductive amination is yet to be the most efficient: the accumulation of alcohol can form irreversibly from the aldehydes on the glycans, which are not stabilized with reducing agents, causing a reduction in efficiency during conjugation [122]. Stabilization of Schiff intermediates would require toxic chemicals, such as borohydride [123]. Also, the level of oxidation when activating the carbohydrates can directly impact carbohydrate:protein ratio of the resultant glycoconjugate [124]. It was documented that while a higher carbohydrate:protein ratio does not positively correlate with immunogenicity, an optimal carbohydrate:protein ratio is necessary to evoke the most robust immune response possible [72].

LPS-based conjugate vaccine candidates for Pseudomonas aeruginosa, Escherichia coli, and Helicobacter pylori have used reductive amination for conjugation [125-127]. Notably, the vaccine candidate against $P$. aeruginosa entered phase 1 trials but was terminated because of a low level of immunogenicity in humans $[128,129]$.

\subsection{Active ester chemistry}

Active ester chemistry is seen extensively in glycoconjugate vaccine candidates which contained synthetic carbohydrates [130]. The mechanism of this approach requires the synthetic oligosaccharides to carry a terminal amino group which allows attachment of di-N-hydroxysuccinimidyl adipate (DSAP) to form a half-ester in dimethyl sulfoxide (DMSO). The halfester, or active ester can readily attach to lysine residues on carrier proteins [130].

Table 3. Glycoconjugate conformations resulting from different chemical conjugation methods applied in LPS-based glycoconjugate vaccine production.

\begin{tabular}{|c|c|c|c|c|}
\hline $\begin{array}{l}\text { Conjugation } \\
\text { method }\end{array}$ & $\begin{array}{l}\text { Glycoconjugate } \\
\text { conformations }\end{array}$ & Advantages & Drawbacks & Reference \\
\hline $\begin{array}{l}\text { Reductive } \\
\text { amination }\end{array}$ & Sun; Lattice & $\begin{array}{l}\text { Well-documented workflow } \\
\text { Have been used in licensed CPS-based } \\
\text { glycoconjugate vaccines }\end{array}$ & $\begin{array}{l}\text { Requires a LPS oxidation step which may damage sugars } \\
\text { Carrier derivatization under low pH may alter epitopes }\end{array}$ & 116,124 \\
\hline $\begin{array}{l}\text { Active ester } \\
\text { chemistry }\end{array}$ & Sun & $\begin{array}{l}\text { Simple workflow when conjugating with } \\
\text { synthetic glycans }\end{array}$ & $\begin{array}{l}\text { Only convenient when working with synthetic glycans carrying } \\
\text { a terminal amino group }\end{array}$ & 130 \\
\hline $\begin{array}{l}\mathrm{CNBr} / \mathrm{ADH} \\
\text { activation }\end{array}$ & Lattice & $\begin{array}{l}\text { Time-proven technique with well- } \\
\text { documented workflow }\end{array}$ & $\begin{array}{l}\text { CNBr is toxic } \\
\text { Conjugation under high } \mathrm{pH} \text { may affect epitopes }\end{array}$ & 116,131 \\
\hline $\begin{array}{l}\text { Squaric acid } \\
\text { chemistry }\end{array}$ & Sun & Quick workflow & $\begin{array}{l}\text { May introduce steric hindrance between glycan and carrier, } \\
\text { causing reduction in immunogenicity }\end{array}$ & 136,139 \\
\hline CDAP chemistry & Lattice & $\begin{array}{l}\text { Easier transition from } \mathrm{CNBr} / \mathrm{ADH} \text { activation } \\
\text { due to similar workflow } \\
\text { CDAP is a nontoxic alternative to } \mathrm{CNBr}\end{array}$ & $\begin{array}{l}\text { Over-crosslinking can happen, causing reduction in } \\
\text { immunogenicity }\end{array}$ & 143 \\
\hline $\begin{array}{l}\text { Aminooxyoxime } \\
\text { chemistry }\end{array}$ & Sun; Lattice & $\begin{array}{l}\text { Simple and well-documented workflow } \\
\text { Does not require extra derivatization of LPS } \\
\text { Mild conjugation conditions may help } \\
\text { preserve epitopes }\end{array}$ & Have not been used in licensed vaccines & 118 \\
\hline Click chemsitry & Sun & Can be performed at room temperature & $\begin{array}{l}\text { May have lower conjugation efficiency than random } \\
\text { conjugation }\end{array}$ & 117,147 \\
\hline
\end{tabular}

a

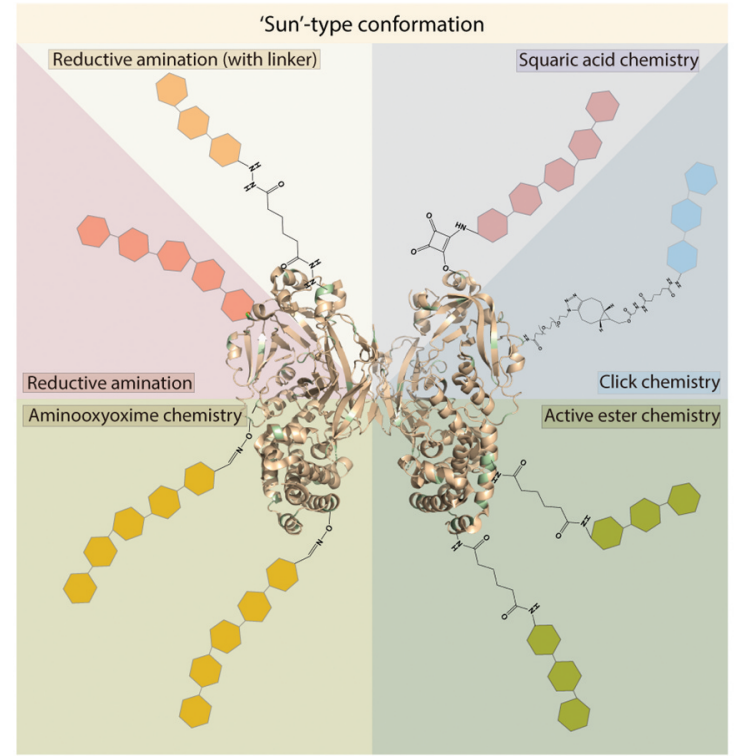

$b$

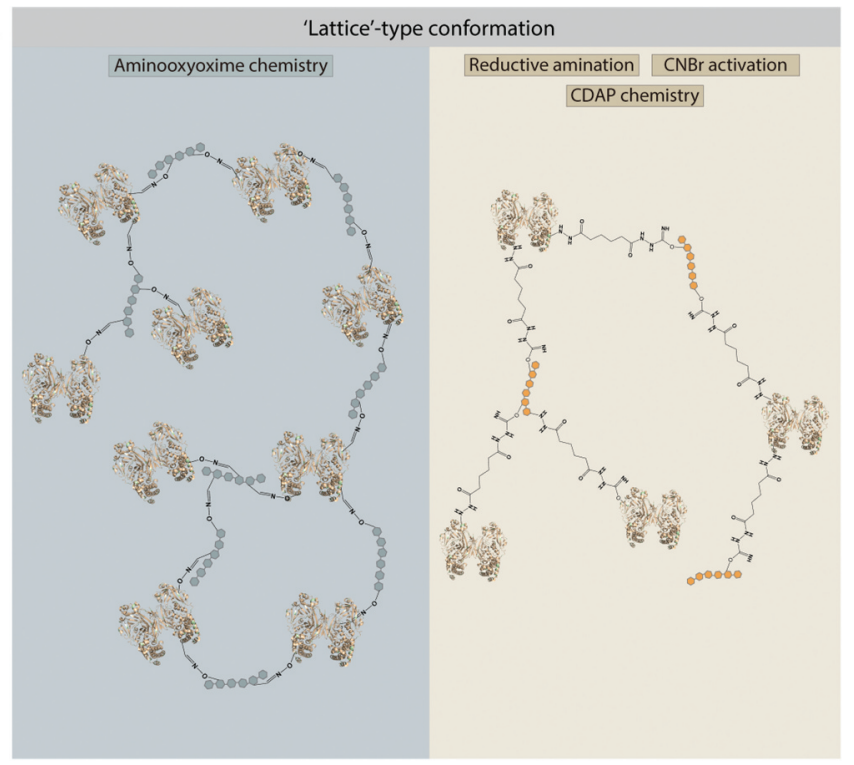

Figure 3. Conformations of chemically conjugated glycoconjugate vaccines. (a) 'Sun'-type glycoconjugates. (b) 'Lattice'-type glycoconjugates. Carrier protein is represented by crystal structure of CRM197 (PDB accession: 4AE1), lysine residues are highlighted in green, linkers are represented by their respective chemical structures attached on lysine residues. Each colored grid represents sugars conjugated to the carrier protein with their respective linkers. 
Active ester chemistry was incorporated in two LPS-based vaccine candidates. More recently, a vaccine candidate comprising synthetic pentasaccharide of $B$. pertussis O-SP to bacteriophage $\mathrm{Q} \beta$ showed a three-fold higher anti-carbohydrate IgG response compared with control groups receiving $\mathrm{Q} \beta$ alone [74]. The method can also be adapted to conjugating $\mathrm{O}-\mathrm{Ag}$ isolated from bacteria by additional linkers such as $\mathrm{ADH}$, as seen in a $S$. Paratyphi A vaccine candidate demonstrated higher anti-O-Ag lgG titers in mice than administering $\mathrm{O}-\mathrm{Ag}$ alone [120].

\subsection{Cyanogen bromide (CNBr) activation}

Activation of glycan with cyanogen bromide is a time-proven technique for sugar-protein conjugation, involving a simple and quick workflow to produce glycoconjugates. The technique has been implemented for several purposes, including conjugate vaccine production, enzyme purification, and biological assay development [131]. In brief, the O-Ag is activated with cyanogen bromide $(\mathrm{CNBr})$ to generate cyanate esters that further reacted with vicinal hydroxyl groups to form cyclic imidocarbonates, which can couple to the carboxyl groups of carrier proteins following 1-ethyl-3-(3-dimethylaminopropyl) carbodiimide (EDC)-mediated condensation.

In vaccine production, $\mathrm{CNBr}$ activation is commonly accompanied by the use of ADH linkers. LPS-based vaccine candidates conjugated via $\mathrm{CNBr}$ activation include ones against $V$. cholerae 0:1 Serotype Inaba [132], V. cholerae 0:1 Serotype Ogawa [133], and Francisella tularensis [134]. All the CNBrconjugated candidates were immunogenic in mice, while several also provided protection to lethal bacterial challenges $[132,134]$. The most notable drawback to this method is the toxicity of $\mathrm{CNBr}$, which may contribute to difficulty in handling. Conjugation conditions using $\mathrm{CNBr}$ are also a potential problem as it requires a high $\mathrm{pH}(\mathrm{pH}=9-10)$, which may interfere with the stability of carbohydrates and proteins [135].

\subsection{Squaric acid chemistry}

Squaric acid chemistry presents a relatively quick and convenient way of conjugation. The use of squaric acid chemistry was first demonstrated in the synthesis of glycoconjugates from synthetic carbohydrates [136]. To carry out conjugation via squaric acid chemistry, the carbohydrate component is linked with a monoamide to the squaric diester. The squarate intermediate can then be reacted with lysine residues in borate buffer $(\mathrm{pH}=9)$ through the formation of 1,2-bisamide of the squaric acid [137].

Reports have suggested that glycoconjugates produced through squaric acid chemistry may be less immunogenic due to the relatively small size of squaric acid, compared with other common linkers such as $\mathrm{ADH}$, thus may result in steric hindrance [138]. Examples of LPS-based vaccine candidates using squaric acid chemistry for conjugation include ones for $V$. cholerae 01 serotypes Inaba and Ogawa, and for $V$. cholerae 0139 [137-139]. Within these, the vaccine candidates for $V$. cholera 01 shown similar IgG titers to administering LPS alone [138]. Similarly, significantly lower anti-CPS IgG was elicited by pneumococcal squaric acid-linked glycoconjugates compared with glycoconjugates using longer linkers, such as ADH [140].

\subsection{1-cyano-4-dimethylaminopyridinium tetrafluoroborate (CDAP) chemistry}

While its mechanism is analogous to $\mathrm{CNBr}$ activation, CDAP chemistry is a newer and potentially better alternative to $\mathrm{CNBr}$ chemistry [141]. Unlike CNBr, CDAP is nontoxic and does not require a high $\mathrm{pH}$ to carry out carbohydrate activation. The mechanism of CDAP activation primarily involves the formation of isourea bonds between cyanoesters on CDAP-activated carbohydrates and $\varepsilon$-amino group of lysine residues on carrier proteins $[142,143]$. As in $\mathrm{CNBr}$ chemistry, ADH is commonly used as a linker in CDAP chemistry.

The primary concern of using CDAP is over-crosslinking. Commonly, over-crosslinked glycoconjugates can cause gelling of carbohydrate and peptides, thus reducing immunogenicity. To overcome this, CDAP chemistry can be performed under an acidic $\mathrm{pH}$ using nucleophilic linkers, such as adipic dihydrazine, which can in turn reduce gelling and restore immunogenicity of the glycoconjugate $[51,143]$.

CDAP chemistry was used in the preclinical development of several LPS-based glycoconjugate vaccine candidates, which induced significantly greater lgG responses in mice against $S$. enterica serovar Enteritidis [144] and S. enterica serovar Paratyphi A than administering O-Ag alone [120,145].

\subsection{Aminooxyoxime chemistry}

Aminooxyoxime chemistry is a precise means of conjugation used in several LPS-based glycoconjugate vaccine developments, which included ones against S. Enteritidis, B. pertussis, S. sonnei, and S. dysenteriae [68,92,144,146]. Aminooxyoxime chemistry allows conjugation to take place at specific moieties of the carbohydrate and proteins, making the result predictable while also being capable of manufacturing glycoconjugates in both 'lattice'-like or 'sun'-like conformations [114].

Both proteins and carbohydrates can be functionalized with an aldehyde or with an aminooxy group. Under a mild acidic condition $(\mathrm{pH}=5)$, the aldehyde-functionalized protein or carbohydrate can readily form oximes with the strong nucleophilic aminooxy group attached on the protein or carbohydrate counterpart [118]. Several ways have been developed to functionalize carbohydrates and polysaccharides for conjugation via aminooxyoxime chemistry, detailly described by Lee, Sen, and LopezAcosta [118].

\subsection{Click chemistry}

Click chemistry allows the attachment of glycans onto specific activated residues on the carrier protein in a 'sun'-like conformation [147]. Click chemistry gained popularity more recently through its increasingly extensive use in conjugating glycoconjugates in biochemical research $[148,149]$. The method works by the ligation between propargylamine-activated glycans and an alkyne-activated carrier protein.

The advantages to click chemistry include that the method can efficiently generate structurally defined ('sun'-type 
conformation) glycoconjugates at room temperature while also having a relatively simple workflow. However, the conjugation efficiency of this method is also lower than those of random conjugation [147]. For LPS-based glycoconjugate vaccines, click chemistry was used to generate vaccine candidates against $S$. Typhimurium, showing an increase of more than 100 -fold in anti-O-Ag lgG titers in murine models $[147,150]$.

\section{Immunological challenges for LPS-based glycoconjugates}

\subsection{Carrier-induced epitopic suppression (CIES)}

The most considerable challenge faced by all glycoconjugate vaccines is likely CIES, which is the reduced immunogenicity of a glycoconjugate when preexisting immunity is present against the same carrier protein it comprises. CIES was welldocumented in past clinical studies as a significant perturbing factor for vaccine efficacies $[151,152]$.

Several mechanisms contributing to CIES have been proposed. One theory suggests the binding of preexisting antibodies against the carrier protein can interfere with the binding of glycoconjugates to B cells, thus disrupting the internalization and the subsequent initiation of antibody responses [153]. Another theory is that previous carrier protein priming would elicit clonal expansion of carrier-specific B cells. This would in turn increase the probability of the glycoconjugate being internalized and degraded by carrier-specific $B$ cells, while preventing the necessary binding to glycan-specific $B$ cells to induce immunity against the glycan moiety of the glycoconjugate [154].

Recent work by Pecetta et al. suggested the possibility that CIES is carrier-dependent. A cohort of mice primed with two different carrier proteins, CRM197 or DT, induced a low antiCRM197 lgG titer and a high anti-DT IgG titer, respectively. The same cohort was then vaccinated with MenA-CRM197 and MenA-DT. As a result, CRM197-primed mice receiving the MenA-CRM197 conjugate showed both anti-carrier and anticarbohydrate IgG responses, while the mice primed with DT before administering the MenA-DT conjugate showed a high anti-carrier and a low anti-carbohydrate IgG response [155]. Thus, the results likely reflected that priming with a less immunogenic carrier does not induce expansion of carrierspecific B cells. In contrast, immunogenic carriers elicit more robust carrier-specific $B$ cell responses that compete with, and prevent, carbohydrate-specific B cell responses [156]. While the mechanisms of CIES are not fully understood, increasing vaccine doses and introducing alternative carrier proteins may help alleviate CIES [157]. In contrast, several studies suggest that priming with a small amount of carrier protein may enhance vaccine efficacy in a dose-dependent manner, highlighting a need for further investigations into the mechanisms of CIES [158-160].

\subsection{Bystander interference}

Like CIES, bystander interference (BI) presents an additional layer of complication in developing and implementing glycoconjugate vaccines. BI happens when multiple glycoconjugate vaccines are introduced concomitantly, causing a decreased immune response to the carbohydrate antigen administered. The current mechanism of bystander interference is that the abundance of conjugates may introduce competition for cytokines and cytokine inhibitors present within the lymph node while resources remain limited $[153,161,162]$.

A well-documented example of $\mathrm{BI}$ is the reduced vaccine efficacy of Hib conjugate vaccines in the UK. The Hib-TT conjugate vaccine, combined with diphtheria-tetanus-acellular pertussis vaccines (DTPa-Hib), was introduced as a routine in the UK in the 1992 [163]. The vaccine's initial results ranged from 0.83 incidents of Hib infection per 100,000 children of $<5$ years of age in 1996 to 0.84 in 1997, and 0.63 in 1998 . However, the figures rose to 1.1 in 1999, followed by 1.8 in 2000, indicating an increase in Hib vaccine failures $[163,164]$. In November 1999, a MenC-CRM197 conjugate vaccine (MCCCRM197) was introduced as a routine 3-dose infant immunization course in the UK [165]. Despite the success in reducing MenC cases in the UK from 1.81 per 100,000 population in $1998 / 1999$ to 0.08 per 100,000 in $2015 / 16$ [162], the concomitant administering of both the MenC conjugate and the Hib conjugate may have contributed to the reduced protection of the Hib conjugate compared with previous years. This was validated by later clinical studies showing the coadministration of MenC-CRM197 and DTPa-inactivated polio (IPV)-Hib in infants produced lower anti-polyribotylribitol phosphate (PRP; a constituent of Hib CPS) titers than receiving DTPa-IPV-Hib alone, while co-administering with MenC-TT resulted in an additional reduction in MenC-TT efficacy [166]. In addition, the coadministration of MenC-CRM197 and DTPa-IPV-Hib showed decreased immunogenicity for all three vaccines after a 3-dose immunization in infants [167]. Statistically significant interference was also reported in concomitant administration of Infanrix-hexa (DTPa-IPV-hepatitis B (HBV)/Hib; GlaxoSmithKline) and Prevenar7 (7-valent pneumococcal vaccine) [168]. While Hib glycoconjugate vaccines are particularly more prone to $\mathrm{Bl}$, other glycoconjugate vaccines also showed small reductions in immunogenicity when co-administered with other vaccines $[162,167]$.

\subsection{Administration and vaccine molecule trafficking}

Several available polysaccharide-based and live attenuated vaccines can be administered subcutaneously, while all licensed glycoconjugate vaccines are administered intramuscularly in the US and the UK $[169,170]$. Despite similar levels of immune responses elicited by these two administration routes, it has been shown that vaccines traffic to physiologically different lymph nodes depending on the proximity to the injection sites, with intramuscular administered vaccine molecules trafficking to lymph nodes further away from the skin in rhesus macaques [171,172]. Additionally, it has been shown that antigen uptake in booster doses can benefit from intramuscular administration compared with subcutaneous administration [172].

While most vaccines are injected, alternative routes of vaccine administration to injection may lead to improved vaccine responses [173]. Oral and nasal administration of vaccines has 
been successful of inducing mucosal immunity. Intramuscular injection is effective in inducing antibodies in the blood, including $\operatorname{lgM}$ and $\lg G$, which are thought to be protective against the spread of bacteria within circulation, but, might offer weaker protection at the sites of primary entry, such as the respiratory tract and the gut mucosa [174]. These sites of primary entry would require the production of IgA or transfer of $\mathrm{lgG}$ from the blood to provide a robust mucosal immunity [173]. Intranasal administration of LPS-AuNP glycoconjugate against Burkholderia mallei showed complete protection against a mouse lethal challenge model, which has also highlighted that novel nanoparticle-based carriers can cross mucosal barriers and inducing a strong immune response [94]. Similarly, PLGA-NPs can induce immune responses intranasally; however, the immune responses correlated with the size of the molecule [175]. A potential caveat to the intranasal administration of LPS-based glycoconjugates is the role of LPS in asthma and pulmonary inflammation. In mouse models, inhaled LPS was shown to recruit eosinophils and neutrophils to the lungs and induce Thelper 2 (Th2) lung inflammation in a dose-dependent manner [176,177].

As for the oral route, LPS-based glycoconjugates have been shown to act as potential boosters to oral live-attenuated vaccines when injected. A synthetic LPS-based glycoconjugate vaccine candidate against $V$. cholera 01 induced a three-fold higher level of stool anti-LPS IgA post-boost compared with oral priming with live attenuated $V$. cholera $\mathrm{O} 1$ alone [71]. Limited attempts were made to use glycoconjugates as an orally administered vaccine. However, a past study has shown that E. coli O-SP conjugated to horse serum albumin did not produce an immune response in mice [178].

\section{Bioconjugation is a newer alternative for glycoconjugate production}

In vivo protein glycan coupling technology (PGCT) involves the bioengineering of bacteria to enable the in vivo coupling of bacterial carbohydrates (like the O-SP of LPS) onto excreted carrier proteins by introducing exogenous genes, while disabling any genes that may perturb its efficiency. These genes include glycan synthesis loci from the carbohydrate of interest, genes encoding oligosaccharyl transferases (OTases), and genes encoding for carrier proteins [179]. Mechanisms, trends, and challenges of the PGCT technology is comprehensively documented in recent reviews [180-182].

The advantage of PGCT-derived bioconjugates compared with chemically conjugated glycoconjugates is that in vivo synthesis would eliminate intermediate steps, thus reduce costs associated with glycan synthesis/harvesting, detoxification, chemical conjugation, and quality control. To date, there are no licensed bioconjugate vaccines. Several LPS-based bioconjugate vaccine candidates are currently recruiting or are undergoing phase 2 clinical trials, this includes bioconjugates against $S$. dysenteriae type 1, S. flexneri 2a, and enteropathogenic E. coli (ClinicalTrials.gov Identifier: NCT04056117; NCT02646371; NCT03500679).
Several technical challenges of PGCT are yet to be addressed. The current technical challenges for PGCT can be summarized as (1) Current OTases are not optimally compatible with all bacterial glycans, producing ununiform bioconjugates; (2) Glycan biosynthesis loci can be challenging to identify and clone, thus not all PGCT can take place in nonpathogenic microbial cell factories as explained below.

\subsection{Coverage and uniformity of chemically conjugated glycoconjugate vaccines compared with bioconjugate vaccines}

LPS is commonly selected as a target for PGCT-derived bioconjugates [181]. Clinical and preclinical LPS-based bioconjugate vaccine candidate includes ones against $E$. coli, F. tularensis, Burkholderia pseudomallei, S. dysenteriae, and S. flexneri $[24,183-187]$. However, the spectrum of pathogens PGCT can cover is dependent on the compatibility between the glycan-based antigens and the OTases. The most widely used OTase, Campylobacter lari PglB, preferentially transfers glycans with a reducing end monosaccharide comprising an acetamido group [188]. Directed protein evolution applied to PglB enhanced its glycan compatibility, resulting in the successful transfer of glycans without a reducing end acetamido group; however, viability and efficiency of this variant may require further assessments [189]. Alternative OTases include Neisseria meningitidis PglL, which also transfers glycans in a preferential manner but has a more relaxed specificity than PglB [190]. Recent work had demonstrated the implementation of Acinetobacter-derived OTase, PgIS, which demonstrated broader compatibility of glycans. PgIS permits glycans containing glucose on the reducing end to be transferred [191].

However, loosening the glycan specificity can also introduce interference from other carbohydrates, thus contaminating the vaccine by making undesired glycoconjugates. Besides the nonspecific transfer of glycans, the uniformity of glycoconjugates is not guaranteed when synthesized in vivo. PGCT typically yields a pool of glycoconjugates with varied molecular masses depending on the length of the glycan, as seen in recent preclinical studies [191-193]. While the effects of this heterogenicity are not yet determined, classic chemical conjugation with synthesized carbohydrates bypasses this potential issue by producing uniform glycans for making glycoconjugates.

\subsection{Safety and yield can be improved for PGCT systems}

In most instances, the identification, cloning, and transfer of all genes relevant to glycan synthesis are necessary for PGCTbased bioconjugate production in well-studied microbial cell factories like E. coli [179]. As E. coli may encode genes for the same purpose as those present in the glycan biosynthesis loci, it is important to deduce the minimal genes required to synthesize the desired bioconjugate [194].

Typically, genes required for glycan biosynthesis are concentrated in a cluster and ubiquitously expressed. However, glycan synthesis genes can be scattered at several loci within 
the genome for certain pathogens, making the identification and cloning of the genes necessary for bioconjugate production difficult. In these cases, in which the biosynthetic genes are not identified, or where it is difficult to transfer them to $E$. coli, studies have circumvented this complication by directly glycoengineering the pathogenic bacterial strains, which have shown to successfully yield bioconjugates. Generation of bioconjugate vaccine candidates against $S$. enterica serovar Paratyphi A and S. flexneri 2a was demonstrated directly from glycoengineered strains of these bacteria [192,195]. However, these bacteria retain pathogenicity and would require cautious handling of these in processes including fermentation, transformation, and harvesting.

As for yield, 100-250 mg of LPS per liter of bacteria culture is typically isolated from the hot phenol-water method in small-scale preclinical production of chemically coupled glycoconjugates [51,63,196-198]. Conjugation efficiency of LPS to a carrier protein can vary depending on the conjugation chemistry and the desired conformation of the glycoconjugates but is typically $>25 \%$ (based on the carbohydrate content) $[196,198,199]$. Thus, an overall estimate of glycoconjugates per liter of culture is $>25 \mathrm{mg}$. In comparison, PGCT-derived bioconjugates typically provide $>5 \mathrm{mg}$ of bioconjugates per liter of culture, perhaps due to the need for media, culturing conditions, and bacterial strain optimization [195].

Additionally, in the case of introducing glycan biosynthesis genes via plasmids, the natural loss of plasmids may reduce the efficiency of PGCT. A previous study has indicated that PGCT efficiencies can be maintained by minimizing the time between cell culture inoculation and induction of PGCT [200].

\section{Conclusion: toward promising LPS-based vaccines}

Despite the increasing number of preclinical LPS-based glycoconjugate vaccine candidates that have arisen in recent years (Table 2), there is still a plethora of Gram-negative bacterial pathogens for which there is still no potent vaccine. These bacteria are viable targets for future LPS-based glycoconjugates. While antibodies to rough-LPS generally show weak protection, developing glycoconjugates which induce antibody responses to the O-SP moiety remains a feasible means of protection against many Gram-negative bacterial pathogens (Table 4).

In conclusion, it is likely that LPS-based conjugate vaccine candidates could begin to play an important role in protection against Gram-negative pathogens in the near future. The efficacy of these glycoconjugates could be improved through the use of conformation-specific conjugation methods, or the use of dual-role carriers. Also, it is important to be alert to the potential for CIES as more glycoconjugate vaccines are used and to monitor for evidence of BI. If the technical hurdles can be overcome, LPS-based conjugates are set to bring a new era of anti-Gram-negative vaccines that will improve human health.

\section{Expert opinions}

The need for broader immunization against Gram-negative bacterial pathogens has driven the rapid development of
LPS-based glycoconjugate vaccines over recent years. As an increasing number of LPS-based glycoconjugate vaccine candidates move toward clinical trials and potential licensure, the emerging demand for large-scale harvesting of LPS is on the horizon. While means to purify smooth LPS remain limited, the recently maturing in situ fermentation, purification, and detoxification techniques can deliver better economic prospects than classic hot phenol-water extraction followed by acid or alkaline detoxification $[51,63]$. In particular, alkaline detoxification has been dismissed in the production of LPS-derivatives due to their unknown toxicity [48]. As an alternative way to obtain LPS, synthetic and semi-synthetic glycan production shows promising yield and efficacy [69]. These platforms are likely to deliver O-SP for LPS-based conjugates with high purity and safety, which may in turn reduce the difficulty of meeting regulatory standards. However, efficacy studies are likely to be needed to elucidate the correlates of protection for LPS-based glycoconjugate vaccines. These studies may require costly investments and thus a potential regulatory hurdle to overcome for LPS-based glycoconjugates.

While novel carriers have shown promising preliminary results, using these carriers in the clinical development of vaccine candidates requires assessments of the efficacy, manufacturability, and scalability of the carriers, thus introducing additional regulatory hurdles in the process [80]. In particular, no licensed vaccines are incorporating nanoparticle-based carriers, which would require careful development and clinical validation. As for dual-role peptide-based carriers, the potential disruption in peptide epitopes when conjugating carbohydrates to carrier proteins can hinder the immunogenicity of the dual-role carrier proteins, requiring a careful selection of conjugation chemistries to avoid $[81,104]$.

Several conjugation chemistries are available for LPS-based glycoconjugate vaccines, but some resulted in the loss of immunogenicity or manufacturability. In most instances, conjugation chemistries will aim to introduce suitable linkers to reduce steric hindrance between sugar and peptide moieties, while also preserving the relevant epitopes in the resultant glycoconjugates [81,119]. To satisfy these aims, methods including reductive amination, CDAP chemistry, and aminooxyoxime chemistry have been more extensively incorporated in LPS-based glycoconjugate vaccine candidates than other techniques $[114,118,120,144]$. Compared to PGCT-derived glycoconjugates, chemically conjugated glycoconjugates bear higher yields while having fewer regulatory hurdles as they are based upon techniques developed over the past decades. However, the PGCT is a fast-evolving technology with rapidly increasing efficiencies, and thus further exploration of its potential is warranted.

Immunological factors are also essential to consider in glycoconjugate vaccine design, such as the interfacing between newly administered glycoconjugates with the preexisting immunity to carrier proteins via CIES, or the potentially reduced immunogenicity with concomitant administration of glycoconjugate vaccines via BI. While CIES has been a persistent problem, novel carriers likely represent the potential solution. Nanoparticle-based carriers and dual-role peptidebased carriers are both likely to be viable avenues toward potential evasion of CIES [151,152]. As for $\mathrm{BI}$, it is likely that 
Table 4. Anti-LPS antibody as correlates to protection in selected pathogenic Gram-negative bacteria.

\begin{tabular}{|c|c|c|c|c|c|c|}
\hline Pathogen & $\begin{array}{l}\text { LPS moiety } \\
\text { providing } \\
\text { protectivity }\end{array}$ & Mechanism & $\begin{array}{l}\text { Other antigens providing } \\
\text { protectivity }\end{array}$ & $\begin{array}{l}\text { Cross-reaction } \\
\text { of anti-LPS } \\
\text { antibodies }\end{array}$ & $\begin{array}{l}\text { Level of } \\
\text { protection }\end{array}$ & Reference \\
\hline $\begin{array}{l}\text { Bordetella } \\
\quad \text { parapertussis }\end{array}$ & O-SP & $\begin{array}{l}\text { Affected the adherence of } \mathrm{B} \text {. } \\
\text { parapertussis to epithelial cells; may } \\
\text { partially contribute to protection. }\end{array}$ & Unknown & Unknown & $\begin{array}{l}\text { Partial } \\
\text { protection }\end{array}$ & {$[201,202]$} \\
\hline $\begin{array}{l}\text { Bordetella } \\
\text { pertussis }\end{array}$ & No & $\begin{array}{l}\text { Rough LPS is a poor immunogen and } \\
\text { fail to contribute to producing } \\
\text { protective antibodies. }\end{array}$ & $\begin{array}{l}\text { pertussis toxin (PT); filamentous } \\
\text { hemagglutinin (FHA); } \\
\text { pertactin (PRN); fimbriae (FIM } \\
2 / 3 \text { ) }\end{array}$ & $\begin{array}{l}\text { with Bordetella } \\
\text { parapertussis }\end{array}$ & $\begin{array}{l}\text { Strong } \\
\text { protection }\end{array}$ & [202-205] \\
\hline Brucella abortus & O-SP & $\begin{array}{l}\text { Complement-dependent bactericidal } \\
\text { activities; Phagocyte-mediated } \\
\text { immunity via opsonization. }\end{array}$ & Omp31 & Unknown & $\begin{array}{l}\text { Strong } \\
\text { protection }\end{array}$ & [206-208] \\
\hline $\begin{array}{l}\text { Burkholderia } \\
\text { mallei }\end{array}$ & O-SP & $\begin{array}{l}\text { Phagocyte-mediated immunity via } \\
\text { opsonization; may partially } \\
\text { contribute to protection. }\end{array}$ & Unknown & $\begin{array}{l}\text { with } \\
\text { Burkholderia } \\
\text { pseudomallei } \\
\text { LPS }\end{array}$ & $\begin{array}{l}\text { Partial } \\
\text { protection }\end{array}$ & {$[94,209-211]$} \\
\hline $\begin{array}{l}\text { Burkholderia } \\
\text { pseudomallei }\end{array}$ & O-SP & $\begin{array}{l}\text { Phagocyte-mediated immunity via } \\
\text { opsonization; IgG2 to LPS } \\
\text { correlative to protection against } \\
\text { lethal infection; may partially } \\
\text { contribute to protection. }\end{array}$ & Unknown & Unknown & $\begin{array}{l}\text { Partial } \\
\text { protection }\end{array}$ & {$[211-214]$} \\
\hline Coxiella burnetii & O-SP & $\begin{array}{l}\text { Likely through phagocyte-mediated } \\
\text { immunity via opsonization. }\end{array}$ & Unknown & Unknown & $\begin{array}{l}\text { Strong } \\
\quad \text { protection }\end{array}$ & {$[215-217]$} \\
\hline $\begin{array}{l}\text { Escherichia coli } \\
\text { rough strain } \\
\text { J5 }\end{array}$ & No & $\begin{array}{l}\text { Rough LPS is a poor immunogen and } \\
\text { fail to contribute to producing } \\
\text { protective antibodies. }\end{array}$ & Unknown & Unknown & $\begin{array}{l}\text { Strong } \\
\text { protection }\end{array}$ & {$[218,219]$} \\
\hline $\begin{array}{l}\text { Escherichia coli } \\
0157\end{array}$ & $\begin{array}{l}\text { O-SP; R3 core } \\
\text { oligosaccharide }\end{array}$ & $\begin{array}{l}\text { Complement-dependent bactericidal } \\
\text { activities; Phagocyte-mediated }\end{array}$ & Flagellin & $\begin{array}{r}\text { with Escherichia } \\
\text { coli 07, } 0116\end{array}$ & $\begin{array}{l}\text { Strong } \\
\quad \text { protection }\end{array}$ & {$[220-222]$} \\
\hline $\begin{array}{l}\text { Escherichia coli } \\
\quad 0111\end{array}$ & O-SP & immunity via opsonization & Unknown & Unknown & & [223] \\
\hline $\begin{array}{l}\text { Escherichia coli } \\
\quad 018\end{array}$ & O-SP & & Unknown & Unknown & & [224] \\
\hline $\begin{array}{l}\text { Francisella } \\
\quad \text { tularensis }\end{array}$ & O-SP & $\begin{array}{l}\text { Likely through phagocyte-mediated } \\
\text { immunity via opsonization }\end{array}$ & $\begin{array}{l}\text { outer membrane protein } A \\
\text { (FopA) }\end{array}$ & Unknown & $\begin{array}{l}\text { Strong } \\
\text { protection }\end{array}$ & {$[225-228]$} \\
\hline $\begin{array}{l}\text { Helicobacter } \\
\text { pylori }\end{array}$ & O-SP & $\begin{array}{l}\text { Promote complement-dependent } \\
\text { inflammation; may partially } \\
\text { contribute to protection. }\end{array}$ & Adhesins & Unknown & $\begin{array}{l}\text { Partial } \\
\text { protection }\end{array}$ & [229-231] \\
\hline $\begin{array}{l}\text { Legionella } \\
\text { pneumophila }\end{array}$ & O-SP & $\begin{array}{l}\text { Phagocyte-mediated immunity via } \\
\text { opsonization. }\end{array}$ & $\begin{array}{l}\text { peptidoglycan-associated } \\
\text { lipoprotein (PAL), } \\
\text { macrophage infectivity } \\
\text { potentiator (Mip), type } \\
\text { IV pilin (PilE), } \\
\text { and flagellin (FlaA) }\end{array}$ & Unknown & $\begin{array}{l}\text { Strong } \\
\text { protection }\end{array}$ & {$[232,233]$} \\
\hline $\begin{array}{l}\text { Mannheimia } \\
\text { haemolytica }\end{array}$ & No & $\begin{array}{l}\text { Rough LPS is a poor immunogen and } \\
\text { fail to contribute to producing } \\
\text { protective antibodies. }\end{array}$ & $\begin{array}{c}\text { OmpA, SSA-1, Gs60, PlpE, TBPs, } \\
\text { PlpF, OmpD15, and OmpP2 }\end{array}$ & Unknown & $\begin{array}{l}\text { Strong } \\
\text { protection }\end{array}$ & {$[234-236]$} \\
\hline $\begin{array}{l}\text { Moraxella } \\
\text { catarrhalis }\end{array}$ & No & $\begin{array}{l}\text { Rough LPS is a poor immunogen and } \\
\text { fail to contribute to producing } \\
\text { protective antibodies; rough LPS } \\
\text { can promote inflammation. }\end{array}$ & UspA & Unknown & $\begin{array}{l}\text { Strong } \\
\text { protection }\end{array}$ & {$[237-239]$} \\
\hline $\begin{array}{l}\text { Neisseria } \\
\quad \text { meningitidis } \\
\text { group B }\end{array}$ & No & $\begin{array}{l}\text { May weakly contribute to } \\
\text { complement-dependent } \\
\text { bactericidal activities; likely not } \\
\text { contributing to protection. }\end{array}$ & $\begin{array}{l}\text { Neisseria adhesin } \mathrm{A}(\mathrm{NadA}) ; \mathrm{H}- \\
\text { binding protein }(\mathrm{fHbp}) ; \\
\text { Neisseria heparin-binding } \\
\text { antigen (NHBA); porin (PorA) }\end{array}$ & Unknown & $\begin{array}{r}\text { Partial or no } \\
\text { protection }\end{array}$ & {$[240-242]$} \\
\hline $\begin{array}{r}\text { Pseudomonas } \\
\text { aeruginosa }\end{array}$ & $\begin{array}{l}\text { O-SP;core } \\
\quad \text { oligosaccharide }\end{array}$ & $\begin{array}{l}\text { Complement-dependent bactericidal } \\
\text { activities; Phagocyte-mediated } \\
\text { immunity via opsonization. }\end{array}$ & $\begin{array}{l}\text { IROMPs, OprC, esterase, OprP, } \\
\text { OprD1, D2, OprE, OprF, OprG, } \\
\text { OprH1, H2, and Oprl. }\end{array}$ & Unknown & $\begin{array}{l}\text { Strong } \\
\text { protection }\end{array}$ & {$[243-246]$} \\
\hline $\begin{array}{l}\text { Salmonella } \\
\text { enterica } \\
\text { serovar } \\
\text { Typhimurium }\end{array}$ & O-SP & $\begin{array}{l}\text { Complement-dependent bactericidal } \\
\text { activities; Phagocyte-mediated } \\
\text { immunity via opsonization; may } \\
\text { partially contribute to protection. }\end{array}$ & Outer membrane proteins & Unknown & $\begin{array}{l}\text { Strong } \\
\text { protection }\end{array}$ & {$[39,247-250]$} \\
\hline $\begin{array}{l}\text { Salmonella } \\
\text { enterica } \\
\text { serovar } \\
\text { Paratyphi }\end{array}$ & O-SP & & FliC & $\begin{array}{l}\text { with S. Typhi } \\
\text { LPS }\end{array}$ & & {$[251-253]$} \\
\hline $\begin{array}{l}\text { Salmonella } \\
\text { enterica } \\
\text { serovar Typhi }\end{array}$ & O-SP & & FliC & $\begin{array}{l}\text { with S. } \\
\text { Paratyphi B } \\
\text { LPS }\end{array}$ & $\begin{array}{l}\text { Partial } \\
\text { protection }\end{array}$ & {$[253,254]$} \\
\hline
\end{tabular}


Table 4. (Continued)

\begin{tabular}{|c|c|c|c|c|c|c|}
\hline Pathogen & $\begin{array}{l}\text { LPS moiety } \\
\text { providing } \\
\text { protectivity }\end{array}$ & Mechanism & $\begin{array}{l}\text { Other antigens providing } \\
\text { protectivity }\end{array}$ & $\begin{array}{l}\text { Cross-reaction } \\
\text { of anti-LPS } \\
\text { antibodies }\end{array}$ & $\begin{array}{l}\text { Level of } \\
\text { protection }\end{array}$ & Reference \\
\hline $\begin{array}{l}\text { Shigella flexneri } \\
2 \mathrm{a}\end{array}$ & O-SP & $\begin{array}{l}\text { Complement-dependent bactericidal } \\
\text { activities }\end{array}$ & $\begin{array}{l}\text { type III secretion system } \\
\text { proteins (IpaB, IpaC); pan } \\
\text { Shigella surface protein-1 } \\
\text { (PSSP-1) }\end{array}$ & $\begin{array}{l}\text { with Shigella } \\
\text { dysenteriae } \\
\text { LPS }\end{array}$ & $\begin{array}{l}\text { Strong } \\
\text { protection }\end{array}$ & {$[54,107,255,256]$} \\
\hline Shigella sonnei & O-SP & & $\begin{array}{l}\text { type III secretion system } \\
\text { proteins (IpaB, IpaC); pan } \\
\text { Shigella surface protein-1 } \\
\text { (PSSP-1) }\end{array}$ & Unknown & & {$[54,255-257]$} \\
\hline $\begin{array}{l}\text { Vibrio cholerae } \\
01 \text { (Inaba) }\end{array}$ & O-SP & $\begin{array}{l}\text { Complement-dependent bactericidal } \\
\text { activities; antibody-mediated }\end{array}$ & Unknown & Unknown & $\begin{array}{l}\text { Strong } \\
\quad \text { protection }\end{array}$ & {$[40,258-260]$} \\
\hline $\begin{array}{r}\text { Vibrio cholerae } \\
01 \text { (Ogawa) }\end{array}$ & O-SP & $\begin{array}{l}\text { inhibition of adhereance and } \\
\text { colonization (in intestine) }\end{array}$ & Unknown & Unknown & & \\
\hline $\begin{array}{l}\text { Vibrio cholerae } \\
0139\end{array}$ & O-SP & & Unknown & Unknown & & \\
\hline
\end{tabular}

BI may emerge as LPS-based glycoconjugate vaccines start to reach licensure. It will also be of interest to identify any vaccine antigens prone to $\mathrm{BI}$, like that seen in CPS-based glycoconjugates $[153,161,162]$. Investigating the potential mechanisms for $\mathrm{Bl}$ would help avoid this problem, hence increasing the efficiency of vaccinations. However, in the cases of $\mathrm{Bl}$, a reduction in immunogenicity can be acceptable if sufficient levels of efficacy are retained, while additional booster doses may help compensate for the reduction. Exploring different administration routes for LPS-based glycoconjugate vaccines is of interest. However, the pro-inflammatory properties of LPS might bring additional difficulties in developing LPS-based glycoconjugates for nasal administration.

Overall, we think that with the development of novel techniques in obtaining LPS, novel carrier proteins, and a better understanding of conjugation chemistries, LPS-based glycoconjugate vaccines are about to emerge as a new category of vaccines that will improve human health.

\section{Funding}

This manuscript is supported by the Innovate UK Vaccines for global development grant (project reference 971619). A J Pollard and C S Rollier are Jenner Investigators.

\section{Acknowledgments}

We acknowledge the support from the National Institute for Health Research (NIHR) Oxford Biochemical Research Centre and Innovate UK.

\section{Declaration of interest}

A J Pollard is Chair of UK Dept. Health and Social Care's (DHSC) Joint Committee on Vaccination \& Immunisation (JCVI), and is a member of the WHO's SAGE. The views expressed in this article do not necessarily represent the views of DHSC, JCVI, or WHO. The University of Oxford has entered into a partnership with AstraZeneca on coronavirus vaccine development. The authors have no other relevant affiliations or financial involvement with any organization or entity with a financial interest in or financial conflict with the subject matter or materials discussed in the manuscript. This includes employment, consultancies, honoraria, stock ownership or options, expert testimony, grants or patents received or pending, or royalties.

\section{Author contribution}

We confirm all authors have (1) substantially contributed to the conception and design of the review article and interpreting the relevant literature, and (2) been involved in writing the review article or revised it for intellectual content.

\section{ORCID}

Henderson Zhu (D) http://orcid.org/0000-0002-5547-6669

\section{References}

Papers of special note have been highlighted as either of interest $(\cdot)$ or of considerable interest $(\cdot \bullet)$ to readers.

1. Tytgat HLP, Lebeer $S$. The sweet tooth of bacteria: common themes in bacterial glycoconjugates. Microbiol Mol Biol Rev. 2014;78 (3):372-417.

2. Heidelberger $M$, Avery OT. The soluble specific substance of pneumococcus. J Exp Med. 1924;40(3):301-316.

3. Finland M, Ruegsegger JM. Immunization of human subjects with the specific carbohydrates of type III and the related type viii pneumococcus. J Clin Invest. 1935;14(6):829-832.

4. Grabenstein JD, Klugman KP. A century of pneumococcal vaccination research in humans. Clin Microbiol Infect. 2012;18(Suppl 5):1524.

5. Smith DH, Peter G, Ingram DL, et al. Responses of children immunized with the capsular polysaccharide of Hemophilus influenzae, type b. Pediatrics. 1973;52(5):637-644.

6. Parke JC, Schneerson R, Robbins JB, et al. Interim report of a controlled field trial of immunization with capsular polysaccharides of Haemophilus influenzae type b and group C Neisseria meningitidis in Mecklenburg county, North Carolina (March 1974 March 1976). J Infect Dis. 1977;136(2):S51-6. Suppl.

7. Pollard AJ, Perrett KP, Beverley PC. Maintaining protection against invasive bacteria with protein- polysaccharide conjugate vaccines. Nat Rev Immunol. 2009;9(3):213-220.

8. Kayhty $\mathrm{H}$, Karanko V, Peltola $\mathrm{H}$, et al. Serum antibodies after vaccination with Haemophilus influenzae type $b$ capsular polysaccharide and responses to reimmunization: no evidence of immunologic tolerance or memory. Pediatrics. 1984;74(5):857-865.

9. Hütter J, Lepenies B. Carbohydrate-based vaccines: an overview. In: Lepenies B, editor. Methods in Molecular Biology. New York: Springer New York; 2015. p. 1-10.

-. This book provided an overview of the history and rationales of glycoconjugate vaccine development.

10. Avery OT, Goebel WF. Chemo-immunological studies on conjugated carbohydrate-proteins : II. immunological specificity of synthetic sugar-protein antigens. J Exp Med. 1929;50(4):533-550. 
11. Lesinski GB, Westerink MA. Novel vaccine strategies to T-independent antigens. J Microbiol Methods. 2001;47(2):135-149.

12. Eskola J, Peltola H, Takala AK, et al. Efficacy of Haemophilus influenzae type $b$ polysaccharide-diphtheria toxoid conjugate vaccine in infancy. N Engl J Med. 1987;317(12):717-722.

13. Vadheim CM, Greenberg DP, Partridge $S$, et al. Effectiveness and safety of an Haemophilus influenzae type $b$ conjugate vaccine (PRPT) in young infants. Kaiser-UCLA Vaccine Study Group. Pediatrics. 1993;92(2):272-279.

14. Mulholland K, Hilton S, Adegbola R, et al. Randomised trial of Haemophilus influenzae type-b tetanus protein conjugate vaccine [corrected] for prevention of pneumonia and meningitis in Gambian infants. Lancet. 1997;349(9060):1191-1197.

15. Trotter CL, McVernon J, Ramsay ME, et al. Optimising the use of conjugate vaccines to prevent disease caused by Haemophilus influenzae type b, Neisseria meningitidis and Streptococcus pneumoniae. Vaccine. 2008;26(35):4434-4445.

16. Davis S, Feikin D, Johnson HL. The effect of Haemophilus influenzae type $B$ and pneumococcal conjugate vaccines on childhood meningitis mortality: a systematic review. BMC Public Health. 2013;13(SUPPL.3):S21.

17. McAllister DA, Liu L, Shi T, et al. Global, regional, and national estimates of pneumonia morbidity and mortality in children younger than 5 years between 2000 and 2015: a systematic analysis. Lancet Glob Heal. 2019;7(1):e47-57.

18. European Medicines Agency [Internet]. https://www.ema. europa.eu/en/medicines [cited 2021 Apr 20]. 2021.

19. Evaluation Center for Biologics Research. Vaccines licensed for use in the US [Internet]. https://www.fda.gov/vaccines-blood-bio logics/vaccines/vaccines-licensed-use-united-states [cited 2021 Apr 20]. 2021.

20. García-Quintanilla M, Pulido MR, Carretero-Ledesma M, et al. Vaccines for antibiotic-resistant bacteria: possibility or pipe dream? Trends Pharmacol Sci. 2016;37(2):143-152.

21. Maldonado RF, Sá-Correia I, Valvano MA. Lipopolysaccharide modification in Gram-negative bacteria during chronic infection. FEMS Microbiol Rev. 2016;40(4):480-493.

22. Farzam N, Ramon-Saraf R, Banet-Levi $Y$, et al. Vaccination with Shigella flexneri 2 a conjugate induces type $2 \mathrm{a}$ and cross-reactive type 6 antibodies in humans but not in mice. Vaccine. 2017;35 (37):4990-4996.

23. Cohen D, Atsmon J, Artaud C, et al. Safety and immunogenicity of a synthetic carbohydrate conjugate vaccine against Shigella flexneri $2 \mathrm{a}$ in healthy adult volunteers: a phase 1, dose-escalating, single-blind, randomised, placebo-controlled study. Lancet Infect Dis. 2020;21(4):546-558.

24. Frenck JRW, Ervin J, Chu L, et al. Safety and immunogenicity of a vaccine for extra-intestinal pathogenic Escherichia coli (ESTELLA): a phase 2 randomised controlled trial. Lancet Infect Dis. 2019;19 (6):631-640.

25. Cryz JSJ, Sadoff JC, Octavalent FE. Pseudomonas aeruginosa Opolysaccharide-toxin A conjugate vaccine. Microb Pathog. 1989;6 (1):75-80.

26. Wang L-X HW. Enzymatic transglycosylation for glycoconjugate synthesis. Curr Opin Chem Biol. 2009;13(5-6):592-600.

27. Middleton DR, Sun L, Paschall AV, et al. Immune responses to type 3 capsular polysaccharide of Streptococcus pneumoniae. J Immunol. 2017;199(2):598-603.

28. Rappuoli R, De Gregorio E, Costantino P. On the mechanisms of conjugate vaccines. Proc Natl Acad Sci U S A. 2019;116(1):14-16.

29. Harding CV, Roof RW, Allen PM, et al. Effects of pH and polysaccharides on peptide binding to class II major histocompatibility complex molecules. Proc Natl Acad Sci U S A. 1991;88(7):27402744.

30. Avci FY, Li X, Tsuji M, et al. A mechanism for glycoconjugate vaccine activation of the adaptive immune system and its implications for vaccine design. Nat Med. 2011;17(12):1602-1609.
- This article suggested a mechanism of glycoconjugate-induced immunity via the interaction between glycopeptides and carbohydrate-specific $T$ cells.

31. Sun X, Stefanetti G, Berti F, et al. Polysaccharide structure dictates mechanism of adaptive immune response to glycoconjugate vaccines. Proc Natl Acad Sci U S A. 2019;116(1):193-198.

32. Silhavy TJ, Kahne D, Walker S. The bacterial cell envelope. Cold Spring Harb Perspect Biol. 2010;2(5):a000414.

33. Beutler B, Rietschel ET. Innate immune sensing and its roots: the story of endotoxin. Nat Rev Immunol. 2003;3(2):169-176.

34. Nikaido H. Molecular basis of bacterial outer membrane permeability revisited. Microbiol Mol Biol Rev. 2003;67(4):593-656.

35. Bertani B, and Ruiz N. Function and Biogenesis of Lipopolysaccharides. EcoSal Plus . 2018;8(1) .

36. Goebel EM, Wolfe DN, Elder K, et al. O antigen protects Bordetella parapertussis from complement. Infect Immun. 2008;76(4):17741780.

37. Plested JS, Ferry BL, Coull PA, et al. Functional opsonic activity of human serum antibodies to inner core lipopolysaccharide (galE) of serogroup B meningococci measured by flow cytometry. Infect Immun. 2001;69(5):3203-3213.

38. Cohen TS, Pelletier M, Cheng $L$, et al. Anti-LPS antibodies protect against Klebsiella pneumoniae by empowering neutrophilmediated clearance without neutralizing TLR4. JCl Insight. 2017;2(9):9.

39. Trebicka E, Jacob S, Pirzai W, et al. Role of antilipopolysaccharide antibodies in serum bactericidal activity against Salmonella enterica serovar Typhimurium in healthy adults and children in the United States. Clin Vaccine Immunol. 2013;20(10):1491-1498.

40. Yang JS, An SJ, Jang MS, et al. IgM specific to lipopolysaccharide of Vibrio cholerae is a surrogate antibody isotype responsible for serum vibriocidal activity. PLoS One. 2019;14(3):e0213507.

41. Schroeder HA, Newby J, Schaefer A, Subramani B, Tubbs A, Gregory Forest $\mathrm{M}$, et al. LPS-binding lgG arrests actively motile Salmonella Typhimurium in gastrointestinal mucus. Mucosal Immunol. 2020;13 (5):814-823

42. Clements A, Jenney AW, Farn JL, et al. Targeting subcapsular antigens for prevention of Klebsiella pneumoniae infections. Vaccine. 2008;26 (44):5649-5653.

43. Park BS, Song DH, Kim HM, et al. The structural basis of lipopolysaccharide recognition by the TLR4-MD-2 complex. Nature. 2009;458(7242):1191-1195.

44. Molinaro A, Holst O, Di LF, et al. Chemistry of lipid a: at the heart of innate immunity. Chem - A Eur J. 2015;21(2):500-519.

45. Lu Y-C, Yeh W-C, Ohashi PS. LPS/TLR4 signal transduction pathway. Cytokine. 2008;42(2):145-151.

46. Neter E, Westphal O, Luderitz O, et al. Studies of enterobacterial lipopolysaccharides; effects of heat and chemicals on erythrocytemodifying, antigenic, toxic and pyrogenic properties. J Immunol. 1956;76(5):377-385.

47. Niwa M, Milner KC, Ribi E, et al. Alteration of physical, chemical, and biological properties of endotoxin by treatment with mild alkali. J Bacteriol. 1969;97(3):1069-1077.

48. Wang Y, Cole RB. Acid and base hydrolysis of lipid A from Enterobacter agglomerans as monitored by electrospray ionization mass spectrometry: pertinence to detoxification mechanisms. J Mass Spectrom. 1996;31(2):138-149.

49. Von Eschen KB, Rudbach JA. Antibody responses of mice to alkaline detoxified lipopolysaccharide. J Immunol. 1976;116(1):8-11.

50. Ding HF, Nakoneczna I, Hsu HS. Protective immunity induced in mice by detoxified Salmonella lipopolysaccharide. J Med Microbiol. 1990;31(2):95-102.

51. Micoli F, Rondini S, Gavini M, et al. A scalable method for O-antigen purification applied to various Salmonella serovars. Anal Biochem. 2013;434(1):136-145.

52. Westphal O, Jann K. Bacterial lipopolysaccharides. Extraction with phenol-water and further applications of the procedures. Methods Carbohydr Chem. 1965;5:83-91. 
53. Apicella MA. Isolation and Characterization of Lipopolysaccharides. In: DeLeo FR, Otto M, editors. Bacterial Pathogenesis: methods and Protocols. Totowa NJ: Humana Press; 2008. p. 3-13.

- This article provided details for the development of LPS extraction and detoxification, including the relevant protocols.

54. Passwell JH, Ashkenzi S, Banet-Levi Y, et al. Age-related efficacy of Shigella O-specific polysaccharide conjugates in 1-4-year-old Israeli children. Vaccine. 2010;28(10):2231-2235.

55. Xu P, Kelly M, Vann WF, et al. Vaccines from bacterial antigens by squaric acid chemistry: a closer look. ChemBioChem. 2017;18 (8):799-815.

56. Johnson KG, Perry MB. Improved techniques for the preparation of bacterial lipopolysaccharides. Can J Microbiol. 1976;22(1):2934.

57. Yi EC, Hackett M. Rapid isolation method for lipopolysaccharide and lipid A from Gram-negative bacteria. Analyst. 2000;125(4):651656.

58. Perry MB, MacLean LL, Schollaardt T, et al. Structural characterization of the lipopolysaccharide $\mathrm{O}$ antigens of Burkholderia pseudomallei. Infect Immun. 1995;63(9):3348-3352.

59. Burtnick MN, Heiss C, Schuler AM, et al. Development of novel Opolysaccharide based glycoconjugates for immunization against glanders. Front Cell Infect Microbiol. 2012;2:148.

60. Muruato LA, Tapia $D$, Hatcher $C L$, et al. Use of reverse vaccinology in the design and construction of nanoglycoconjugate vaccines against Burkholderia pseudomallei. Clin Vaccine Immunol. 2017;24 (11):11.

61. Hirschfeld $M, M a ~ Y$, Weis $\mathrm{JH}$, et al. Cutting edge: repurification of lipopolysaccharide eliminates signaling through both human and murine toll-like receptor 2. J Immunol. 2000;165(2):618-622.

62. Hisatsune $K$, Iguchi $T$, Kondo $S$, et al. Method for sugar analysis of lipopolysaccharides of gram-negative bacteria. Syst Appl Microbiol. 1990;13(4):320-326.

63. Rondini S, Micoli F, Lanzilao L, et al. Design of glycoconjugate vaccines against invasive African Salmonella enterica serovar Typhimurium. Infect Immun. 2015;83(3):996-1007.

64. Galanos C, Lüderitz O, Westphal O, et al. Method for the extraction of R lipopolysaccharides. Eur J Biochem. 1969;9(2):245-249.

65. Brade L, Hensen S, Brade H. Evaluation of a LPS-based glycoconjugate vaccine against bovine Escherichia coli mastitis: formation of LPS Abs in cows after immunization with $E$. coli core oligosaccharides conjugated to hemocyanine. Innate Immun. 2013;19(4):368377.

66. Darveau RP, Hancock REW. Procedure for isolation of bacterial lipopolysaccharides from both smooth and rough Pseudomonas aeruginosa and Salmonella typhimurium strains. J Bacteriol. 1983;155(2):831-838.

67. Costantino P, Rappuoli R, Berti F. The design of semi-synthetic and synthetic glycoconjugate vaccines. Expert Opin Drug Discov. 2011;6(10):1045-1066.

68. Pozsgay V, Kubler-Kielb J, Schneerson R, et al. Effect of the nonreducing end of Shigella dysenteriae type $1 \mathrm{O}$-specific oligosaccharides on their immunogenicity as conjugates in mice. Proc Natl Acad Sci U S A. 2007;104(36):14478-14482.

69. Colombo C, Pitirollo O, Lay L. Recent advances in the synthesis of glycoconjugates for vaccine development. Molecules. 2018;23:7.

-. This review article provided insights on the synthesis of glycans for glycoconjugate vaccine development against bacterial and fungal pathogens.

70. Reinhardt A, Yang Y, Claus H, et al. Antigenic potential of a highly conserved Neisseria meningitidis lipopolysaccharide inner core structure defined by chemical synthesis. Chem Biol. 2015;22 (1):38-49.

71. Tarique AA, Kalsy A, Arifuzzaman M, et al. Transcutaneous immunization with a Vibrio cholerae 01 Ogawa synthetic hexasaccharide conjugate following oral whole-cell cholera vaccination boosts vibriocidal responses and induces protective immunity in mice. Clin Vaccine Immunol. 2012;19(4):594-602.

72. Pozsgay V, Chu C, Pannell L, et al. Protein conjugates of synthetic saccharides elicit higher levels of serum IgG lipopolysaccharide antibodies in mice than do those of the O-specific polysaccharide from Shigella dysenteriae type 1. Proc Natl Acad Sci U S A. 1999;96 (9):5194-5197.

73. Rollenhagen JE, Kalsy A, Saksena R, et al. Transcutaneous immunization with a synthetic hexasaccharide-protein conjugate induces anti-Vibrio cholerae lipopolysaccharide responses in mice. Vaccine. 2009;27(36):4917-4922.

74. Wang P, Huo C X, Lang S, et al. Chemical synthesis and immunological evaluation of a pentasaccharide bearing multiple rare sugars as a potential anti-pertussis vaccine. Angew Chemie Int Ed. 2020;59(16):6451-6458.

75. Guberman M, Seeberger PH. Automated glycan assembly: a perspective. J Am Chem Soc. 2019;141(14):5581-5592.

76. Hahm HS, Schlegel MK, Hurevich $M$, et al. Automated glycan assembly using the glyconeer 2.1 synthesizer. Proc Natl Acad Sci U S A. 2017;114(17):E3385-9.

77. Sletten ET, Danglad-Flores J, Nuño $M$, et al. Automated glycan assembly in a variable-bed flow reactor provides insights into oligosaccharide-resin interactions. Org Lett. 2020;22(11):42134216.

78. McCarthy PC, Saksena R, Peterson DC, et al. Chemoenzymatic synthesis of immunogenic meningococcal group $C$ polysialic acidtetanus Hc fragment glycoconjugates. Glycoconj J. 2013;30(9):857870.

79. Li L, Woodward RL, Han W, et al. Chemoenzymatic synthesis of the bacterial polysaccharide repeating unit undecaprenyl pyrophosphate and its analogs. Nat Protoc. 2016;11(7):1280-1298.

80. Pichichero ME. Protein carriers of conjugate vaccines: characteristics, development, and clinical trials. Hum Vaccin Immunother. 2013;9(12):2505-2523.

- This review article provides an overview of carrier proteins, including rationales for conjugating, comparison between traditional and novel carriers, and conjugation chemistries.

81. Micoli F, Adamo R, Costantino P. Protein carriers for glycoconjugate vaccines: history, selection criteria, characterization and new trends. Molecules. 2018;23(6):6.

82. Cross AS, Greenberg N, Billington $M$, et al. Phase 1 testing of detoxified LPS/group B meningococcal outer membrane protein vaccine with and without synthetic CPG 7909 adjuvant for the prevention and treatment of sepsis. Vaccine. 2015;33(48):67196726.

83. St Michael F, Cairns C, Filion AL, et al. Investigating the candidacy of lipopolysaccharide-based glycoconjugates as vaccines to combat Mannheimia haemolytica. Glycoconj J. 2011;28(6):397-410.

84. Cox AD, St. Michael F, Cairns CM, et al. Investigating the potential of conserved inner core oligosaccharide regions of Moraxella catarrhalis lipopolysaccharide as vaccine antigens: accessibility and functional activity of monoclonal antibodies and glycoconjugate derived sera. Glycoconj J. 2011;28(3-4):165-182.

85. Al-Zeer M, Masoud H. LPS-based conjugate vaccines composed of O-polysaccharide from Pseudomonas aeruginosa IATS 6 and 11 bound to a carrier protein. World J Microbiol Biotechnol. 2007;23 (11):1541-1549.

86. Ravenscroft N, Haeuptle MA, Kowarik M, et al. Purification and characterization of a Shigella conjugate vaccine, produced by glycoengineering Escherichia coli. Glycobiology. 2016;26(1):51-62.

87. Kubler-Kielb J, Vinogradov E, Mocca $C$, et al. Immunochemical studies of Shigella flexneri $2 a$ and 6, and Shigella dysenteriae type 1 O-specific polysaccharide-core fragments and their protein conjugates as vaccine candidates. Carbohydr Res. 2010;345(11):16001608.

88. Paulovičová E, Korcová J, Farkaš $\mathrm{P}$, et al. Immunological efficacy of glycoconjugates derived from Vibrio cholerae 01 serotype Ogawa detoxified LPS in mice. J Med Microbiol. 2010;59(12):1440-1448.

89. Fleischhackerová-Slimáková A, Korcová J, Bystrický S Immunogenicity of a glycoconjugate from hydrazine-detoxified lipopolysaccharide of Vibrio cholerae 0139. Scand J Immunol. 2017;86(6):444-451.

90. Sayeed MA, Bufano MK, and $\mathrm{Xu} P$, et al. A cholera conjugate vaccine containing ospecific polysaccharide (OSP) of $V$. cholera 01 
inaba and recombinant fragment of tetanus toxin heavy chain (OSP: $\mathrm{rTTHC}$ ) induces serum, memory and lamina proprial responses against OSP and is protective in mice PLoS Negl Trop Dis. 2015;9(7).

91. Kubler-Kielb J. Conjugation of LPS-derived oligosaccharides to proteins using oxime chemistry. In: Mark SS, editor. Methods in Molecular Biology. Totowa NJ: Humana Press; 2011. p. 317-327.

92. Robbins JB, Kubler-Kielb J, Vinogradov E, et al. Synthesis, characterization, and immunogenicity in mice of Shigella sonnei O-specific oligosaccharide-core-protein conjugates. Proc Natl Acad Sci U S A. 2009;106(19):7974-7978.

93. Safari D, Marradi M, Chiodo F, et al. Gold nanoparticles as carriers for a synthetic Streptococcus pneumoniae type 14 conjugate vaccine. Nanomedicine. 2012;7(5):651-662.

94. Tapia D, Sanchez-Villamil Jl, Torres AG. Multicomponent gold nanoglycoconjugate as a highly immunogenic and protective platform against Burkholderia mallei. Npj Vaccines. 2020;5(1):1-11.

95. Niikura K, Matsunaga T, Suzuki T, et al. Gold nanoparticles as a vaccine platform: influence of size and shape on immunological responses in vitro and in vivo. ACS Nano. 2013;7(5):3926-3938.

96. Hočevar S, Milošević A, Rodriguez-Lorenzo L, et al. Polymer-coated gold nanospheres do not impair the innate immune function of human B lymphocytes in vitro. ACS Nano. 2019;13(6):6790-6800.

97. Wilson KL, Howard GP, Coatsworth H, et al. PLGA-b-PEG nanoparticles induce $T$ helper 2 (Th2) immune responses and sustained antibody titers via TLR9 stimulation. Vaccines (Basel). 2020;8:2.

98. Afshari H, Maleki M, Salouti M. Immunological effects of two new nanovaccines against Brucella based on OPS and LPS antigens conjugated with PLGA nanoparticles. Eur Polym J. 2020;139:110021.

99. Gu P, Wusiman A, Zhang Y, et al. Polyethylenimine-coated PLGA nanoparticles-encapsulated Angelica sinensis polysaccharide as an adjuvant for H9N2 vaccine to improve immune responses in chickens compared to Alum and oil-based adjuvants. Vet Microbiol. 2020;251:108894.

100. Gornati L, Zanoni I, Granucci F. Dendritic cells in the cross hair for the generation of Tailored Vaccines. Front Immunol. 2018;9 (JUN):1484.

101. Huang SS, Li IH, Da HP, et al. Development of Yersinia pestis F1 antigen-loaded microspheres vaccine against plague. Int $J$ Nanomedicine. 2014;9(1):813-822.

102. Tan Z, Liu W, Liu H, et al. Oral Helicobacter pylori vaccine-encapsulated acid-resistant HP55/PLGA nanoparticles promote immune protection. Eur J Pharm Biopharm. 2017;111:33-43.

103. Ashhurst AS, Parumasivam T, Chan JGY, et al. PLGA particulate subunit tuberculosis vaccines promote humoral and Th17 responses but do not enhance control of Mycobacterium tuberculosis infection. PLoS One. 2018;13(3):e0194620.

104. Bröker M, Berti F, Schneider J, et al. Polysaccharide conjugate vaccine protein carriers as a "neglected valency" - Potential and limitations. Vaccine. 2017;35(25):3286-3294.

105. Di Benedetto R, Mancini F, Carducci M, et al. Rational design of a glycoconjugate vaccine against group A streptococcus. Int J Mol Sci. 2020;21:22.

106. Laird RM, Ma Z, Dorabawila N, et al. Evaluation of a conjugate vaccine platform against enterotoxigenic Escherichia coli (ETEC), Campylobacter jejuni and Shigella. Vaccine. 2018;36(45):66956702.

107. Cohen D, Meron-Sudai S, Bialik A, et al. Serum IgG antibodies to Shigella lipopolysaccharide antigens - a correlate of protection against shigellosis. Hum Vaccin Immunother. 2019;15(6):1401-1408.

108. Evans DG, Graham DY, Evans JDJ. Administration of purified colonization factor antigens (CFA/I, CFA/II) of enterotoxigenic Escherichia coli to volunteers. Response to challenge with virulent enterotoxigenic Escherichia coli. Gastroenterology. 1984;87(4):934-940.

109. Andrade GR, New RRC, Sant'Anna OA, et al. A universal polysaccharide conjugated vaccine against 0111 E. coli. Hum Vaccines Immunother. 2014;10(10):2864-2874.
110. Duan $Q$, Xia P, Nandre R, et al. Review of newly identified functions associated with the heat-labile toxin of enterotoxigenic Escherichia coli. Front Cell Infect Microbiol. 2019;9:292.

111. Szenborn L, Osipova IV, Czajka H, et al. Immunogenicity, safety and reactogenicity of the pneumococcal non-typeable Haemophilus influenzae protein D conjugate vaccine (PHiD-CV) in 2-17-year-old children with asplenia or splenic dysfunction: a phase 3 study. Vaccine. 2017;35(40):5331-5338.

112. Qian W, Huang Z, Chen Y, et al. Elicitation of integrated immunity in mice by a novel pneumococcal polysaccharide vaccine conjugated with HBV surface antigen. Sci Rep. 2020;10(1):6470.

113. Bröker M. Potential protective immunogenicity of tetanus toxoid, diphtheria toxoid and Cross Reacting Material 197 (CRM197) when used as carrier proteins in glycoconjugates. Hum Vaccin Immunother. 2016;12(3):664-667.

114. Kubler-Kielb J, Pozsgay V. A new method for conjugation of carbohydrates to proteins using an aminooxy-thiol heterobifunctional linker. J Org Chem. 2005;70(17):6987-6990.

115. St Michael F, Cairns CM, Filion AL, et al. Investigating the candidacy of LPS-based glycoconjugates to prevent invasive meningococcal disease: conjugates based on core oligosaccharides. Glycoconj J. 2014;31(1):25-39.

116. Barel L-A-A, Mulard LA. Classical and novel strategies to develop a Shigella glycoconjugate vaccine: from concept to efficacy in human. Hum Vaccin Immunother. 2019;15(6):1338-1356.

117. Nilo A, Allan M, Brogioni $B$, et al. Tyrosine-directed conjugation of large glycans to proteins via copper-free click chemistry. Bioconjug Chem. 2014;25(12):2105-2111.

118. Lees A, Sen G, Lopezacosta A. Versatile and efficient synthesis of protein-polysaccharide conjugate vaccines using aminooxy reagents and oxime chemistry. Vaccine. 2006;24(6):716-729.

119. Hevey R, and CC L. Conjugation Strategies Used for the Preparation of Carbohydrate-Conjugate Vaccines. In: Narain R, editor. Chemistry of Bioconjugates: synthesis, Characterization, and Biomedical Applications. New Jersey (United States): John Wiley \& Sons; 2014. p. 387-413

120. Micoli F, Rondini S, Gavini M, et al. O:2-CRM(197) conjugates against Salmonella Paratyphi A. PLoS One. 2012;7(11):e47039.

121. Likhosherstov LM, Novikova OS, Derevitskaja VA, et al. A new simple synthesis of amino sugar $\beta$-d-glycosylamines. Carbohydr Res. 1986;146(1):C1-5.

122. Saksena R, Chernyak A, and Poirot $E$, et al. Conjugating Low Molecular Mass Carbohydrates to Proteins 2. Recovery of Excess Ligand Used in the Conjugation Reaction, Methods Enzymol. 2003;362: 140-159.

123. Jennings $H J$, Lugowski $C$. Immunochemistry of groups $A, B$, and $C$ meningococcal polysaccharide-tetanus toxoid conjugates. J Immunol. 1981;127(3):1011-1018.

124. Stefanetti G, Rondini S, Lanzilao L, et al. Impact of conjugation chemistry on the immunogenicity of $S$. Typhimurium conjugate vaccines. Vaccine. 2014;32(46):6122-6129.

125. Cryz JSJ, Furer E, Sadoff JC, et al. Pseudomonas aeruginosa immunotype 5 polysaccharide-toxin A conjugate vaccine. Infect Immun. 1986;52(1):161-165.

126. Cryz JSJ, Que JO, Cross AS, et al. Synthesis and characterization of a polyvalent Escherichia coli O-polysaccharide-toxin A conjugate vaccine. Vaccine. 1995;13(5):449-453.

127. Altman E, Chandan V, Harrison B. The potential of dextran-based glycoconjugates for development of Helicobacter pylori vaccine. Glycoconj J. 2014;31(1):13-24.

128. Lang $A B$, Rüdeberg $A$, Schöni $M H$, et al. Vaccination of cystic fibrosis patients against Pseudomonas aeruginosa reduces the proportion of patients infected and delays time to infection. Pediatr Infect Dis J. 2004;23(6):504-510.

129. Zuercher AW, Horn MP, Que JU, et al. Antibody responses induced by long-term vaccination with an octovalent conjugate Pseudomonas aeruginosa vaccine in children with cystic fibrosis. FEMS Immunol Med Microbiol. 2006;47(2):302-308. 
130. Adamo R, Tontini M, Brogioni G, et al. Synthesis of laminarin fragments and evaluation of a $\beta-(1,3)$ glucan hexasaccarideCRM197 conjugate as vaccine candidate against Candida albicans. J Carbohydr Chem. 2011;30(4-6):249-280.

131. Axén R, Porath J, Ernback S. Chemical coupling of peptides and proteins to polysaccharides by means of cyanogen halides. Nature. 1967;214(5095):1302-1304.

132. Grandjean C, Wade TK, Ropartz D, et al. Acid-detoxified Inaba lipopolysaccharide (pmLPS) is a superior cholera conjugate vaccine immunogen than hydrazine-detoxified lipopolysaccharide and induces vibriocidal and protective antibodies. Pathog Dis. 2013;67 (2):136-158

133. Ftacek $\mathrm{P}$, Nelson V, and Szu SC. Immunochemical characterization of synthetic hexa-, octa- and decasaccharide conjugate vaccines for Vibrio cholerae 0:1 Serotype Ogawa with emphasis on antigenic density and chain length. Glycoconj J. 2013;30:871-880.

134. Stefanetti G, Okan N, Fink A, et al. Glycoconjugate vaccine using a genetically modified $O$ antigen induces protective antibodies to Francisella tularensis. Proc Natl Acad Sci U S A. 2019;116(14):70627070.

135. Kohn J, Wilchek M. The use of cyanogen bromide and other novel cyanylating agents for the activation of polysaccharide resins. Appl Biochem Biotechnol. 1984;9(3):285-305.

136. Tietze LF, Schroeter C, Gabius S, et al. Conjugation of p-aminophenyl glycosides with squaric acid diester to a carrier protein and the use of the neoglycoprotein in the histochemical detection of lectins. Bioconjug Chem. 1991;2(3):148-153.

137. Alam MM, Bufano MK, Xu P, et al. Evaluation in mice of a conjugate vaccine for cholera made from Vibrio cholerae 01 (Ogawa) O-specific polysaccharide. PLoS Negl Trop Dis. 2014;8(2):e2683.

138. Xu P, Alam MM, Kalsy A, et al. Simple, direct conjugation of bacterial O-SP-core antigens to proteins: development of cholera conjugate vaccines. Bioconjug Chem. 2011;22(10):2179-2185.

139. Xu P, Korcová J, Baráth $\mathrm{P}$, et al. Isolation, purification, characterization and direct conjugation of the lipid A-free lipopolysaccharide of Vibrio cholerae 0139. Chem - A Eur J. 2019;25(56):12946-12956.

140. Mawas F, Niggemann J, Jones C, et al. Immunogenicity in a mouse model of a conjugate vaccine made with a synthetic single repeating unit of type 14 pneumococcal polysaccharide coupled to CRM197. Infect Immun. 2002;70(9):5107-5114.

141. Chiu TW, Peng CJ, Chen MC, et al. Constructing conjugate vaccine against Salmonella Typhimurium using lipid-A free lipopolysaccharide. J Biomed Sci. 2020;27(1):89.

142. Lees A, Nelson BL, Mond JJ. Activation of soluble polysaccharides with 1-cyano-4-dimethylaminopyridinium tetrafluoroborate for use in protein-polysaccharide conjugate vaccines and immunological reagents. Vaccine. 1996;14(3):190-198.

143. Shafer DE, Toll B, Schuman RF, et al. Activation of soluble polysaccharides with 1-cyano-4-dimethylaminopyridinium tetrafluoroborate (CDAP) for use in protein-polysaccharide conjugate vaccines and immunological reagents. II. Selective crosslinking of proteins to CDAP-activated polysaccharides. Vaccine. 2000;18(13):1273-1281.

144. Simon R, Tennant SM, Wang JY, et al. Salmonella enterica Serovar Enteritidis core $\mathrm{O}$ Polysaccharide conjugated to $\mathrm{H}$ : g,mFlagellin as a candidate vaccine for protection against invasive infection with S. Enteritidis. Infect Immun. 2011;79(10):4240-4249.

145. Ali A, An SJ, Cui C, et al. Synthesis and immunogenicity evaluation of Salmonella enterica serovar Paratyphi A O-specific polysaccharide conjugated to diphtheria toxoid. Hum Vaccin Immunother. 2014;10(6):1494-1498.

146. Kubler-Kielb J, Vinogradov E, Lagergård T, et al. Oligosaccharide conjugates of Bordetella pertussis and bronchiseptica induce bactericidal antibodies, an addition to pertussis vaccine. Proc Natl Acad Sci U S A. 2011;108(10):4087-4092.

147. Stefanetti G, Allan M, Usera A, et al. Click chemistry compared to thiol chemistry for the synthesis of site-selective glycoconjugate vaccines using CRM197 as carrier protein. Glycoconj J. 2020;37 (5):611-622.

148. Stefanetti G, Saul A, MacLennan CA, et al. Click chemistry applied to the synthesis of Salmonella Typhimurium O-antigen glycoconjugate vaccine on solid phase with sugar recycling. Bioconjug Chem. 2015;26(12):2507-2513.

149. Lin L, Qiao M, Zhang $X$, et al. Site-selective reactions for the synthesis of glycoconjugates in polysaccharide vaccine development. Carbohydr Polym. 2020;230:115643.

150. Stefanetti G, Hu Q-Y, Usera A, et al. Sugar-protein connectivity impacts on the immunogenicity of site-selective Salmonella O-antigen glycoconjugate vaccines. Angew Chem Int Ed Engl. 2015;54 (45):13198-13203.

151. Tashani M, Alfelali M, Barasheed O, et al. Effect of Tdap upon antibody response to meningococcal polysaccharide when administered before, with or after the quadrivalent meningococcal TT-conjugate vaccine (coadministered with the 13-valent pneumococcal CRM197-conjugate vaccine) in adult Hajj pilgrims: a randomised controlled trial. Vaccine. 2018;36(29):4375-4382.

152. McCluskie MJ, Evans DM, Zhang N, et al. The effect of preexisting anti-carrier immunity on subsequent responses to CRM197 or Qb-VLP conjugate vaccines. Immunopharmacol Immunotoxicol. 2016;38(3):184-196.

153. Dagan R, Poolman J, Siegrist CA. Glycoconjugate vaccines and immune interference: a review. Vaccine. 2010;28(34):5513-5523.

- This article suggested that binding of pre-existing antibodies to the carrier proteins induces CIES.

154. Schutze MP, Deriaud E, Przewlocki G, et al. Carrier-induced epitopic suppression is initiated through clonal dominance. J Immunol. 1989;142(8):2635-2640.

- This article suggested that the abundance of carrier-specific B cells induces $\mathrm{CIES}$ after an initial carrier priming.

155. Pecetta S, Lo Surdo P, Tontini M, et al. Carrier priming with CRM197 or diphtheria toxoid has a different impact on the immunogenicity of the respective glycoconjugates: biophysical and immunochemical interpretation. Vaccine. 2015;33(2):314-320.

156. Pecetta S, Tontini M, Faenzi $E$, et al. Carrier priming effect of CRM197 is related to an enhanced B and $T$ cell activation in meningococcal serogroup A conjugate vaccination. Immunological comparison between CRM197 and diphtheria toxoid. Vaccine. 2016;34(20):2334-2341.

157. Di John D, Torres JR, Murillo J, et al. Effect of priming with carrier on response to conjugate vaccine. Lancet. 1989;334 (8677):1415-1418.

158. Peeters CCAM, Tenbergen-Meekes AM, Poolman JT, et al. Effect of carrier priming on immunogenicity of saccharide-protein conjugate vaccines. Infect Immun. 1991;59(10):3504-3510.

159. Granoff DM, Holmes SJ, Osterholm MT, et al. Induction of immunologic memory in infants primed with Haemophilus influenzae Type b conjugate vaccines. J Infect Dis. 1993;168(3):663-671.

160. Pobre K, Tashani M, Ridda I, et al. Carrier priming or suppression: understanding carrier priming enhancement of anti-polysaccharide antibody response to conjugate vaccines. Vaccine. 2014;32 (13):1423-1430.

161. Insel RA. Potential alterations in immunogenicity by combining or simultaneously administering vaccine components. Ann N Y Acad Sci. 1995;754(1):35-48.

- This article suggested that BI results from an abundance of glycoconjugates leading to a competition for resources within the lymph node.

162. Findlow H, Borrow R. Interactions of conjugate vaccines and coadministered vaccines. Hum Vaccines Immunother. 2016;12(1):226230 .

163. Heath PT, The MJ. UK hib vaccine experience. Arch Dis Child. 2002;86(6):396-399.

164. Dagan R, Poolman JT, Zepp F. Combination vaccines containing DTPa-Hib: impact of IPV and coadministration of CRM197 conjugates. Expert Rev Vaccines. 2008;7(1):97-115.

165. Miller E, Salisbury D, Ramsay M. Planning, registration, and implementation of an immunisation campaign against meningococcal serogroup C disease in the UK: a success story. Vaccine. 2001;20 (SUPPL. 1):S58-67.

166. Kitchin NRE, Southern J, Morris R, et al. Evaluation of a diphtheriatetanus-acellular pertussis-inactivated poliovirus-Hae-mophilus 
influenzae type $\mathrm{b}$ vaccine given concurrently with meningococcal group C conjugate vaccine at 2, 3 and 4 months of age. Arch Dis Child. 2007;92(1):11-16.

167. Moss SJ, Fenton AC, Toomey J, et al. Immunogenicity of a heptavalent conjugate pneumococcal vaccine administered concurrently with a combination diphtheria, tetanus, five-component acellular pertussis, inactivated polio, and Haemophilus influenzae type $b$ vaccine and a meningococcal group C c. Clin Vaccine Immunol. 2010;17(3):311-316.

168. Boot HJ, Schipper CMA. Simultaneous vaccination with prevenar and multicomponent vaccines for children: interference or no interference? Hum Vaccin. 2009;5(1):15-17.

169. Centers for Disease Control and Prevention. Vaccine Administration Route and Site [Internet]. https://www.cdc.gov/vaccines/hcp/ admin/administer-vaccines.html [cited 2021 Apr 20]. 2021.

170. Vaccine Administration Taskforce, British Travel Health Association, Community Practitioners' and Health Visitors' Association, Royal College of General Practitioners, Royal College of Nursing (Great Britain), Association of Occupational Health Nurse Practitioners. UK guidance on best practice in vaccine administration. Shire Hall Communications; 2001.

171. Mark A, Carlsson RM, Granström M. Subcutaneous versus intramuscular injection for booster DT vaccination of adolescents. Vaccine. 1999;17(15-16):2067-2072.

172. Ols S, Yang L, Thompson EA, et al. Route of vaccine administration alters antigen trafficking but not innate or adaptive immunity. Cell Rep. 2020;30(12):3964-3971.e7.

173. Holmgren J, Czerkinsky C. Mucosal immunity and vaccines. Nat Med. 2005;11(4 Suppl):S45-53.

174. Herva $E$, Luotonen J, Timonen M, et al. The effect of polyvalent pneumococcal polysaccharide vaccine on nasopharyngeal and nasal carriage of Streptococcus pneumoniae. Scand J Infect Dis. 1980;12(2):97-100.

175. Gutierro I, Hernández RM, Igartua M, et al. Size dependent immune response after subcutaneous, oral and intranasal administration of BSA loaded nanospheres. Vaccine. 2002;21(1-2):67-77.

176. Daan de Boer J, Jjth R, de Vos AF, et al. Lipopolysaccharide inhibits Th2 lung inflammation induced by house dust mite allergens in mice. Am J Respir Cell Mol Biol. 2013;48(3):382-389.

177. Kumari A, Dash D, Lipopolysaccharide SR. (LPS) exposure differently affects allergic asthma exacerbations and its amelioration by intranasal curcumin in mice. Cytokine. 2015;76(2):334-342.

178. Conlan JW, KuoLee R, Webb A, et al. Oral immunization of mice with a glycoconjugate vaccine containing the 0157 antigen of Escherichia coli 0157: h7admixed with cholera toxin fails to elicit protection against subsequent colonization by the pathogen. Can J Microbiol. 2000;46(3):283-290.

179. Wacker $M$, Linton $D$, Hitchen PG, et al. N-linked glycosylation in Campylobacter jejuni and its functional transfer into E. coli. Science. 2002;298(5599):1790-1793.

180. Kay E, Cuccui J, Wren BW. Recent advances in the production of recombinant glycoconjugate vaccines. Npj Vaccines. 2019;4 (1):16.

181. Micoli F, Del Bino L, Alfini R, et al. Glycoconjugate vaccines: current approaches towards faster vaccine design. Expert Rev Vaccines. 2019;18(9):881-895

- This review article highlighted the current technical routes for glycoconjugate vaccine development.

182. Dow JM, Mauri M, Scott TA, et al. Improving protein glycan coupling technology (PGCT) for glycoconjugate vaccine production. Expert Rev Vaccines. 2020;19(6):507-527.

.- This review article highlighted the principles, recent developments, and bacterial strains used in PGCT, while giving an overview of the vaccine candidates derived from PGCT.

183. Cuccui J, Thomas RM, Moule MG, et al. Exploitation of bacterial Nlinked glycosylation to develop a novel recombinant glycoconjugate vaccine against Francisella tularensis. Open Biol. 2013;3 (5):130002.

184. Garcia-Quintanilla F, Iwashkiw JA, Price NL, et al. Production of a recombinant vaccine candidate against Burkholderia pseudomallei exploiting the bacterial N-glycosylation machinery. Front Microbiol. 2014;5:381.

185. Hatz CFR, Bally B, Rohrer S, et al. Safety and immunogenicity of a candidate bioconjugate vaccine against Shigella dysenteriae type 1 administered to healthy adults: a single blind, partially randomized Phase I study. Vaccine. 2015;33(36):4594-4601.

186. Riddle MS, Kaminski RW, Di Paolo C, et al. Safety and immunogenicity of a candidate bioconjugate vaccine against Shigella flexneri $2 \mathrm{a}$ administered to healthy adults: a single-blind, randomized phase I study. Clin Vaccine Immunol. 2016;23(12):908-917.

187. Ravenscroft N, Braun M, Schneider J, et al. Characterization and immunogenicity of a Shigella flexneri 2a O-antigen bioconjugate vaccine candidate. Glycobiology. 2019;29(9):669-680.

188. Wacker M, Feldman MF, Callewaert N, et al. Substrate specificity of bacterial oligosaccharyltransferase suggests a common transfer mechanism for the bacterial and eukaryotic systems. Proc Natl Acad Sci U S A. 2006;103(18):7088-7093.

189. Ihssen J, Haas J, Kowarik $M$, et al. Increased efficiency of Campylobacter jejuni $\mathrm{N}$-oligosaccharyltransferase PglB by structure-guided engineering. Open Biol. 2015;5(4):140227.

190. Faridmoayer A, Fentabil MA, Mills DC, et al. Functional characterization of bacterial oligosaccharyltransferases involved in O-linked protein glycosylation. J Bacteriol. 2007;189(22):8088-8098.

191. Harding CM, Nasr MA, Scott NE, et al. A platform for glycoengineering a polyvalent pneumococcal bioconjugate vaccine using $E$. coli as a host. Nat Commun. 2019;10(1):891.

192. Sun P, Pan C, Zeng M, et al. Design and production of conjugate vaccines against $S$. Paratyphi $A$ using an O-linked glycosylation system in vivo. Npj Vaccines. 2018;3(1):4

193. Feldman MF, Mayer Bridwell $A E$, Scott $N E$, et al. A promising bioconjugate vaccine against hypervirulent Klebsiella pneumoniae. Proc Natl Acad Sci U S A. 2019;116(37):18655-18663.

194. Kay EJ, Yates LE, Terra VS, et al. Recombinant expression of Streptococcus pneumoniae capsular polysaccharides in Escherichia coli. Open Biol. 2016;6(4):150243.

195. Pan C, Sun $P$, Liu B, et al. Biosynthesis of conjugate vaccines using an O-linked glycosylation system. MBio. 2016;7(2):e00443-16.

196. Chu C, Liu B, Watson D, et al. Preparation, characterization, and immunogenicity of conjugates composed of the O-specific polysaccharide of Shigella dysenteriae type 1 (Shiga's bacillus) bound to tetanus toxoid. Infect Immun. 1991;59(12):4450-4458.

197. Yu S, Gu XX. Biological and immunological characteristics of lipooligosaccharide-based conjugate vaccines for serotype C Moraxella catarrhalis. Infect Immun. 2007;75(6):2974-2980.

198. Taylor DN, Trofa AC, Sadoff J, et al. Synthesis, characterization, and clinical evaluation of conjugate vaccines composed of the O-specific polysaccharides of Shigella dysenteriae type 1, Shigella flexneri type 2a, and Shigella sonnei (Plesiomonas shigelloides) bound to bacterial toxoids. Infect Immun. 1993;61(9):3678-3687.

199. Altman E, Chandan V, Harrison BA, et al. Structural and immunological characterization of a glycoconjugate based on the delipidated lipopolysaccharide from a nontypeable Helicobacter pylori strain PJ1 containing an extended D-glycero-D-manno-heptan. Carbohydr Res. 2018;456:19-23.

200. Ihssen J, Kowarik M, Dilettoso S, et al. Production of glycoprotein vaccines in Escherichia coli. Microb Cell Fact. 2010;9(1):61.

201. Van Den Berg BM, Beekhuizen H, Mooi FR, et al. Role of antibodies against Bordetella pertussis virulence factors in adherence of Bordetella pertussis and Bordetella parapertussis to human bronchial epithelial cells. Infect Immun. 1999;67(3):1050-1055.

202. Trollfors B, Lagergård T, Taranger J, et al. Serum immunoglobulin $G$ antibody responses to Bordetella pertussis lipooligosaccharide and B. parapertussis lipopolysaccharide in children with pertussis and parapertussis. Clin Diagn Lab Immunol. 2001;8(5):1015-1017.

203. Caroff M, Chaby R, Karibian D, et al. Variations in the carbohydrate regions of Bordetella pertussis lipopolysaccharides: electrophoretic, serological, and structural features. J Bacteriol. 1990;172(2):11211128.

204. Geurtsen J, Fae KC, van den Dobbelsteen GPJM. Importance of (antibody-dependent) complement-mediated serum killing in 
protection against Bordetella pertussis. Expert Rev Vaccines. 2014;13 (10):1229-1240.

205. Cherry JD, Heininger U, Richards DM, et al. Antibody response patterns to Bordetella pertussis antigens in vaccinated (primed) and unvaccinated (unprimed) young children with pertussis. Clin Vaccine Immunol. 2010;17(5):741-747.

206. Elzer PH, Jacobson RH, Jones SM, et al. Antibody-mediated protection against Brucella abortus in BALB/c mice at successive periods after infection: variation between virulent strain 2308 and attenuated vaccine strain 19. Immunology. 1994;82(4):651-658.

207. Cloeckaert A, Vizcaíno N, Paquet J-Y, et al. Major outer membrane proteins of Brucella spp.: past, present and future. Vet Microbiol. 2002;90(1-4):229-247.

208. Bhattacharjee AK, Van de Verg L, Izadjoo MJ, et al. Protection of mice against brucellosis by intranasal immunization with Brucella melitensis lipopolysaccharide as a noncovalent complex with Neisseria meningitidis group B outer membrane protein. Infect Immun. 2002;70(7):3324-3329.

209. Moustafa DA, Scarff JM, Garcia PP, et al. Recombinant Salmonella expressing Burkholderia mallei LPS O antigen provides protection in a murine model of melioidosis and glanders. PLoS One. 2015;10(7): e0132032.

210. Tamigney Kenfack $M$, Mazur $M$, Nualnoi T, et al. Deciphering minimal antigenic epitopes associated with Burkholderia pseudomallei and Burkholderia mallei lipopolysaccharide O-antigens. Nat Commun. 2017;8(1):115.

211. Silva EB, Dow SW. Development of Burkholderia mallei and pseudomallei vaccines. Front Cell Infect Microbiol. 2013;3:10.

212. Nelson M, Prior JL, Lever MS, et al. Evaluation of lipopolysaccharide and capsular polysaccharide as subunit vaccines against experimental melioidosis. J Med Microbiol. 2004;53(Pt 12):1177-1182.

213. Scott $A E$, Ngugi $S A$, Laws TR, et al. Protection against experimental melioidosis following immunisation with a lipopolysaccharide-protein conjugate. J Immunol Res. 2014;2014:392170.

214. Chaichana P, Jenjaroen K, Chumseng S, et al. Role of Burkholderia pseudomallei-specific $\operatorname{lgG} 2$ in adults with acute melioidosis, Thailand. Emerg Infect Dis. 2021;27(2):463-470.

215. Zhang G, Russell-Lodrigue KE, Andoh $M$, et al. Mechanisms of vaccine-induced protective immunity against Coxiella burnetii infection in BALB/c mice. J Immunol. 2007;179(12):8372-8380.

216. Williams JC, Hoover TA, Waag DM, et al. Antigenic structure of Coxiella burnetii. A comparison of lipopolysaccharide and protein antigens as vaccines against Q fever. Ann N Y Acad Sci. 1990;590(1 Rickettsiolog):370-380.

217. Shannon JG, Cockrell DC, Takahashi K, et al. Antibody-mediated immunity to the obligate intracellular bacterial pathogen Coxiella burnetii is FC receptor- and complement-independent. BMC Immunol. 2009;10(1):26.

218. Baumgartner JD, Heumann D, Calandra T, et al. Antibodies to lipopolysaccharides after immunization of humans with the rough mutant Escherichia coli J5. J Infect Dis. 1991;163(4):769-772.

219. Bhattacharjee AK, Opal SM, Palardy JE, et al. Affinity-purified Escherichia coli J5 lipopolysaccharide-specific lgG protects neutropenic rats against gram-negative bacterial sepsis. J Infect Dis. 1994;170(3):622-629.

220. Currie CG, McCALLUM K, Poxton IR. Mucosal and systemic antibody responses to the lipopolysaccharide of Escherichia coli 0157 in health and disease. J Med Microbiol. 2001;50(4):345-354.

221. Navarro A, Eslava C, Hernandez U, et al. Antibody responses to Escherichia coli $\mathrm{O} 157$ and other lipopolysaccharides in healthy children and adults. Clin Diagn Lab Immunol. 2003;10(5):797801.

222. McNeilly TN, Naylor SW, Mahajan A, et al. Escherichia coli 0157: h7colonization in cattle following systemic and mucosal immunization with purified $\mathrm{H} 7$ flagellin. Infect Immun. 2008;76 (6):2594-2602.

223. Oishi K, Koles NL, Guelde G, et al. Antibacterial and protective properties of monoclonal antibodies reactive with Escherichia coli 0111: b4lipopolysaccharide: relation to antibody isotype and complement-fixing activity. J Infect Dis. 1992;165(1):34-45.
224. Schiff DE, Wass CA, Cryz JSJ, et al. Estimation of protective levels of anti-O-specific lipopolysaccharide immunoglobulin $G$ antibody against experimental Escherichia coli infection. Infect Immun. 1993;61(3):975-980.

225. Mechaly A, Elia U, Alcalay R, et al. Inhibition of Francisella tularensis phagocytosis using a novel anti-LPS ScFv antibody fragment. Sci Rep. 2019;9(1):11418.

226. Fulop M, Mastroeni P, Green M, et al. Role of antibody to lipopolysaccharide in protection against low- and high-virulence strains of Francisella tularensis. Vaccine. 2001;19(31):4465-4472.

227. Del Barrio L, Sahoo M, Lantier L, et al. Production of anti-LPS IgM by $B 1 a$ B cells depends on IL-1 $\beta$ and is protective against lung infection with Francisella tularensis LVS. PLoS Pathog. 2015;11(3): e1004706.

228. Hickey AJ, Hazlett KRO, Kirimanjeswara GS, et al. Identification of Francisella tularensis outer membrane protein A (FopA) as a protective antigen for tularemia. Vaccine. 2011;29(40):6941-6947.

229. Taylor JM, Ziman ME, Huff JL, et al. Helicobacter pylori lipopolysaccharide promotes a Th1 type immune response in immunized mice. Vaccine. 2006;24(23):4987-4994.

230. Mahdavi J, Sondén B, Hurtig M, et al. Helicobacter pylori SabA adhesin in persistent infection and chronic inflammation. Science. 2002;297(5581):573-578.

231. Chmiela M, Miszczyk E, Rudnicka K. Structural modifications of Helicobacter pylori lipopolysaccharide: an idea for how to live in peace. World J Gastroenterol. 2014;20(29):9882-9897.

232. Weber SS, Ducry J, Oxenius A. Dissecting the contribution of IgG subclasses in restricting airway infection with Legionella pneumophila. J Immunol. 2014;193(8):4053-4059.

233. He J, Huang F, Chen $\mathrm{H}$, et al. Recombinant Mip-PilE-FlaA dominant epitopes vaccine candidate against Legionella pneumophila. Immunol Lett. 2017;186:33-40.

234. Confer AW, Ayalew S. Mannheimia haemolytica in bovine respiratory disease: immunogens, potential immunogens, and vaccines. Anim Heal Res Rev. 2018;19(2):79-99

235. Ali Q, Davies RL, Parton R, et al. Lipopolysaccharide heterogeneity in Pasteurella haemolytica isolates from cattle and sheep. J Gen Microbiol. 1992;138(10):2185-2195.

236. Confer AW, Panciera RJ, Mosier DA. Serum antibodies to Pasteurella haemolytica lipopolysaccharide: relationship to experimental bovine pneumonic pasteurellosis. Am J Vet Res. 1986;47(5):11341138.

237. Rahman M, Holme T, Jönsson I, et al. Lack of serotype-specific antibody response to lipopolysaccharide antigens of Moraxella catarrhalis during lower respiratory tract infection. Eur J Clin Microbiol Infect Dis. 1995;14(4):297-304.

238. Helminen ME, Maciver I, Latimer JL, et al. A large, antigenically conserved protein on the surface of Moraxella catarrhalis is a target for protective antibodies. J Infect Dis. 1994;170(4):867872.

239. Hassan F, Ren D, Zhang W, et al. Moraxella catarrhalis activates murine macrophages through multiple toll like receptors and has reduced clearance in lungs from TLR4 mutant mice. PLoS One. 2012;7(5):e37610

240. Skevakis L, Frasch CE, Zahradnik JM, et al. Class-specific human bactericidal antibodies to capsular and noncapsular surface antigens of Neisseria meningitidis. J Infect Dis. 1984;149 (3):387-396.

241. Schmiel DH, Moran EE, Keiser PB, et al. Importance of antibodies to lipopolysaccharide in natural and vaccine-induced serum bactericidal activity against Neisseria meningitidis group B. Infect Immun. 2011;79(10):4146-4156.

242. Toneatto $D$, Ismaili $S$, Ypma $E$, et al. The first use of an investigational multicomponent meningococcal serogroup $B$ vaccine (4CMenB) in humans. Hum Vaccin. 2011;7(6):646-653.

243. Hemachandra S, Kamboj K, Copfer J, et al. Human monoclonal antibodies against Pseudomonas aeruginosa lipopolysaccharide derived from transgenic mice containing megabase human immunoglobulin loci are opsonic and protective against fatal pseudomonas sepsis. Infect Immun. 2001;69(4):2223-2229. 
244. Stanislavsky ES, Lam JS. Pseudomonas aeruginosa antigens as potential vaccines. FEMS Microbiol Rev. 1997;21(3):243-277.

245. Secher T, Fauconnier L, Szade A, et al. Anti-Pseudomonas aeruginosa serotype 011 LPS immunoglobulin $M$ monoclonal antibody panobacumab (KBPA101) confers protection in a murine model of acute lung infection. J Antimicrob Chemother. 2011;66(5):11001109.

246. Hancock RE, Siehnel R, Martin N. Outer membrane proteins of Pseudomonas. Mol Microbiol. 1990;4(7):1069-1075.

247. Colwell DE, Michalek SM, Briles DE, et al. Monoclonal antibodies to Salmonella lipopolysaccharide: anti-O-polysaccharide antibodies protect $\mathrm{C} 3 \mathrm{H}$ mice against challenge with virulent Salmonella typhimurium. J Immunol. 1984;133(2):950-957.

248. McSorley SJ, Jenkins MK. Antibody is required for protection against virulent but not attenuated Salmonella enterica serovar typhimurium. Infect Immun. 2000;68(6):3344-3348.

249. Goh YS, Clare S, Micoli F, et al. Monoclonal antibodies of a diverse isotype induced by an O-antigen glycoconjugate vaccine mediate In Vitro and In Vivo killing of African invasive nontyphoidal Salmonella. Infect Immun. 2015;83(9):3722-3731.

250. Rondini S, Lanzilao L, Necchi F, et al. Invasive African Salmonella Typhimurium induces bactericidal antibodies against O-antigens. Microb Pathog. 2013;63:19-23.

251. Boyd MA, Tennant SM, Saague VA, et al. Serum bactericidal assays to evaluate typhoidal and nontyphoidal Salmonella vaccines. Clin Vaccine Immunol. 2014;21(5):712-721.

252. Gat O, Galen JE, Tennant S, et al. Cell-associated flagella enhance the protection conferred by mucosally-administered attenuated Salmonella Paratyphi A vaccines. PLoS Negl Trop Dis. 2011;5(11): e1373.
253. Wahid R, Simon R, Zafar SJ, et al. Live oral typhoid vaccine Ty21a induces cross-reactive humoral immune responses against Salmonella enterica serovar Paratyphi A and S. Paratyphi B in humans. Clin Vaccine Immunol. 2012;19(6):825-834.

254. Juel HB, Thomaides-Brears HB, Darton TC, et al. Salmonella typhi bactericidal antibodies reduce disease severity but do not protect against typhoid fever in a controlled human infection Model. Front Immunol. 2017;8:1916.

255. Kim J-O, Rho S, Kim SH, et al. Shigella outer membrane protein PSSP-1 is broadly protective against Shigella infection. Clin Vaccine Immunol. 2015;22(4):381-388.

256. Heine SJ, Diaz-McNair J, Andar AU, et al. Intradermal delivery of Shigella IpaB and IpaD type III secretion proteins: kinetics of cell recruitment and antigen uptake, mucosal and systemic immunity, and protection across serotypes. J Immunol. 2014;192(4):1630-1640.

257. Chowers Y, Kirschner J, Keller N, et al. O-specific polysaccharide conjugate vaccine-induced antibodies prevent invasion of Shigella into Caco-2 cells and may be curative. Proc Natl Acad Sci U S A. 2007;104(7):2396-2401.

258. Johnson RA, Uddin T, Aktar A, et al. Comparison of immune responses to the O-specific polysaccharide and lipopolysaccharide of Vibrio cholerae $\mathrm{O} 1$ in Bangladeshi adult patients with cholera. Clin Vaccine Immunol. 2012;19(11):1712-1721.

259. Uddin T, Harris JB, Bhuiyan TR, et al. Mucosal immunologic responses in cholera patients in Bangladesh. Clin Vaccine Immunol. 2011;18(3):506-512.

260. Mukhopadhyay S, Nandi B, Ghose AC. Antibodies (IgG) to lipopolysaccharide of Vibrio cholerae $\mathrm{O} 1$ mediate protection through inhibition of intestinal adherence and colonisation in a mouse model. FEMS Microbiol Lett. 2000;185(1):29-35. 